\title{
A Historical Review of Management Options Used against the Stable Fly (Diptera: Muscidae)
}

\author{
David Cook \\ Department of Primary Industries and Regional Development, South Perth, WA 6151, Australia; \\ david.cook3@dpird.wa.gov.au; Tel.:+61-8-9368-3084
}

Received: 3 April 2020; Accepted: 11 May 2020; Published: 15 May 2020

check for updates

\begin{abstract}
The stable fly, Stomoxys calcitrans (L.) (Diptera: Muscidae), remains a significant economic pest globally in situations where intensive animal production or horticultural production provide a suitable developmental medium. Stable flies have been recorded as pests of livestock and humans since the late 1800s to early 1900s. Over 100 years of research has seen numerous methodologies used to control this fly, in particular to protect cattle from flies to minimise production losses. Reduced milk production in dairy cows and decreased weight gain in beef cattle account for losses in the US alone of $>$ \$2000 million annually. Rural lifestyles and recreation are also seriously affected. Progress has been made on many control strategies against stable fly over a range of chemical, biological, physical and cultural options. This paper reviews management options from both a historical and a technical perspective for controlling this pest. These include the use of different classes of insecticides applied to affected animals as toxicants or repellents (livestock and humans), as well as to substrates where stable fly larvae develop. Arthropod predators of stable flies are listed, from which potential biological control agents (e.g., wasps, mites, and beetles) are identified. Biopesticides (e.g., fungi, bacteria and plant-derived products) are also discussed along with Integrated Pest Management (IPM) against stable flies for several animal industries. A review of cultural and physical management options including trapping, trap types and methodologies, farm hygiene, scheduled sanitation, physical barriers to fly emergence, livestock protection and amendments added to animal manures and bedding are covered. This paper presents a comprehensive review of all management options used against stable flies from both a historical and a technical perspective for use by any entomologist, livestock producer or horticulturalist with an interest in reducing the negative impact of this pest fly.
\end{abstract}

Keywords: insecticide; biopesticide; entomopathogenic fungi; insect growth regulator; wasps; parasitoid; traps; sanitation; repellent; compaction

\section{Introduction}

The stable fly, Stomoxys calcitrans (Diptera: Muscidae), remains a significant economic pest globally in places where either intensive animal production or horticultural production provide a suitable developmental medium. Accumulations of animal manure, soiled bedding, wet hay and silage [1] and rotting plant material (reject produce, abandoned crops, processing waste) can produce substrates that support stable fly larval development [2-4].

Stable flies have been recorded as pests of livestock and humans dating back to the late 1800s to early 1900s. The first record of stable flies affecting livestock was in 1889, when a new cattle pest was reported in the American Naturalist by Williston [5]. Protecting cows from flies (including stable flies) was noted in Connecticut, US in the early 1900s [6]. By the early 1900-1910s, articles were being published on the life history and bionomics of stable flies [6-9]. Reduced weight gain can occur with as few as 20 flies per animal $[10,11]$. Cattle often bunch together when attacked by stable flies to avoid being bitten; this often leads to heat stress and reduced feeding [12-14]. Serum levels of the stress 
hormone cortisol increased in dairy cows in response to higher numbers of stable flies on them and their associated fly-dislodging behaviors [15]. Their painful bites can reduce milk production in dairy cows, decrease weight gain in beef cattle and affect feed efficiency [16] with national losses in cattle production for the US alone being over $\$ 2$ billion [17]. Rural lifestyle and recreation are also seriously affected in peri-urban and rural communities [18,19].

Several factors make stable flies difficult to control: (i) this fly only visits its host briefly to obtain a blood meal, making chemical control difficult; (ii) larval developmental sites are widespread and often ephemeral; and iii) stable flies are strong fliers, hence adequate control requires area-wide efforts [20]. Progress has been made on many control options against this blood-feeding fly covering a broad range of chemical, biological, physical and cultural options along with trapping for monitoring and fly reduction [4]. A previous review of the importance of S. calcitrans as a livestock pest in 2018 only briefly discussed chemical, biological and cultural control options [21]. This paper presents a comprehensive review of management options from both a historical perspective and as a resource for any entomologist, livestock producer or horticulturalist with an interest in control and management strategies that have been used previously to reduce the impact of this pest fly.

\section{Chemicals}

\subsection{Insecticides}

The use of insecticides against stable flies dates back to the early 1900s, where the first record in the literature on stable fly control was by Beach and Clark [6], who wrote about protecting cows from flies. Over that century, insecticide use moved from dichloro-diphenyl-trichloroethane (DDT), organochlorines, carbamates and organophosphates to pyrethrins, both on animals directly and in situations where larval infestations of stable fly were found (e.g., rotting hay, soiled animal bedding, rotting vegetable matter) [22]. Various authors have reviewed a range of pesticides against stable flies, with Mount et al. $[23,24]$ providing the most comprehensive evaluations. These two laboratory studies combined tested $>230$ compounds against adults and 390 compounds against larvae in treated media. Subsequently, the toxicity of various insecticides to stable flies has been reviewed [25-28].

Since the early 1930s, significant discoveries led to the proliferation of new synthetic pesticides including organochlorines, organophosphates and pyrethroids [29]. Plant-derived pesticides such as rotenone (isoflavone) and pyrethrum were applied as dusts on cattle to control stable flies in 1936 [30]. DDT was one of the first modern synthetic insecticides developed to combat mainly insect-borne human diseases (e.g., malaria and typhus) among both military and civilian populations. DDT was highly effective against stable flies both in animal barns [31,32] and in larval infestations in shore deposits of marine grass [33]. However, within a decade, DDT resistance was detected in stable fly populations [34-36]. Dichloro-diphenyl-dichloroethane (DDD) is a metabolite of DDT considered to be less toxic to animals than DDT. Applications of $1 \%$ spray solutions of DDD on cattle provided equivalent control of stable flies as DDT [37]. The organochlorine dieldrin was widely used between the 1950s and 1970s in agriculture [38] but, similar to DDT, it came and went within a decade for use against stable flies [39] once resistance quickly developed [40].

Pine tar creosote was shown as early as 1917 to protect dairy cattle from stable flies [41]. Creosote oil and diesel controlled larval infestations of stable flies in marine grass accumulations [42,43]. Similarly, gas condensate produced by the carbonisation of coal was tested as a cheap and readily available toxic agent against stable fly larvae infesting grasses, peanut vine litter and celery crop residues [44]. However, mass accumulations of waste celery could not be adequately treated by insecticides or gas condensate due to their sheer volume $\left(260,000 \mathrm{~m}^{3}\right)$ and density of stable fly larvae $\left(\approx 2 \mathrm{million} / \mathrm{m}^{3}\right)[22]$. Preventative spraying schedules to reduce anticipated outbreaks of stable flies were successful for dairy farms in the 1960s using carbamates and organophosphates [45]. Fogging and spraying with various insecticides were effective at reducing stable flies in milking sheds and barns (DDT [31]; dimethoate [46]; pyrethrin [47]; resmethrin [48]. 
Methoxychlor (organochloride), toxaphene and DDT (now mostly obsolete due to environmental and human health concerns) caused rapid knockdown and death of stable flies and maintained a residual efficacy for several months [49]. This led to organochlorines being applied to the exterior surfaces of animal barns to reduce stable flies. The next major group of chemicals used against stable flies were the organophosphates (e.g., dimethoate, chlorpyifos, crotoxyphos), thiophosphates (e.g., dichlorvos) and phosphothiorates (e.g., coumaphos), which have been available as insect control agents since the 1950s. Following the demise of DDT, organophosphates quickly followed as the pesticides of choice against stable flies. Stable flies were controlled on Norwegian farms with trichlorfon [35] and crotoxyphos was used against stable flies on dairy cattle [50]. Aerial application of insecticides to dairy farms and feedlots resulted in reductions in stable fly numbers between a maximum of $60 \%$ on dairy farms and up to $90 \%$ on feedlots when assessed $24 \mathrm{~h}$ after application of the organophosphates naled, fenthion and dichlorvos [51].

The next major group of pesticides used against stable flies were the synthetic pyrethroids (SP), which were far more effective at killing insects than DDT, but without the negative impacts on human health [52] and the environment [53]. Cyclethrin was used on cattle and effective control of stable flies was observed [54]. The pyrethroid resmethrin applied as a dust by compressed gas into a $425 \mathrm{~m}^{3}$ barn effectively killed all flies including stable, house and lesser house fly [48]. Schmidt et al. [55] evaluated an SP on cattle and observed effective control of stable flies for $8 \mathrm{~d}$ after treatment. Permethrin applied as a backline treatment to cattle controlled stable flies for up to 2 weeks [56] and improved milk yield in dairy cows by $0.8 \mathrm{~kg} /$ animal [57]. Permethrin-soaked tape attached to the ears and tails of dairy cattle provided up to 10 weeks control of stable flies [58,59].

Stable fly populations in Mexican dairy farms were susceptible to permethrin when assessed in 2005 [60]. Five years later, signs of permethrin resistance were evident in Florida stable fly populations [61] and first noted in European populations soon after [62,63]. Most recently, the widespread use of insecticides against stable fly outbreaks in Brazil have resulted in the populations around sugar cane mills in the state of Mato Grosso do Sul becoming resistant to cypermethrin, with resistance factors up to 39 [64]. Similarly, Reissert-Opperman et al. [65] found that stable flies across dairy farms in Germany were $100 \%$ resistant to deltamethrin.

\subsection{Systemic Insecticides}

The catalyst to search for a systemic insecticide toxic to insects, but non-toxic to the host was provided when wheat grown in soil containing sodium selenate was not attacked by the aphid Macrosiphum granarium Kirby [66]. McGregor and Bushland [67] attributed the first success at internal administration of an insecticide in controlling a bloodsucking insect to Lindquist et al. [68] where rabbits tolerated both DDT and a pyrethrum extract given orally, which resulted in their blood being toxic to bed bugs. Over 10 years, Drummond [69-77] reviewed and screened multiple animal systemic insecticides against stable flies, which was first reported in the mid-1950s [67]. Complete mortality of adult stable flies occurred with repeated feedings of $5 \mathrm{ppm}$ of benzimidazole levels in blood [78]. Although many anthelmintic drugs administered to animals leave residues of the drug in the treated animal's dung where they can impair fly development in the dung, these residues also have both lethal and sublethal effects on non-target dung fauna $[79,80]$.

\subsection{Insect Growth Regulators (IGRs)}

IGRs act by preventing fly larvae from successfully moulting through to the next larval instar by interrupting the synthesis of chitin. Additionally, the juvenilizing activity of ecdysones prevent the adult fly from emerging from the pupal case [81]. Active ingredients that have been used against stable flies include cyromazine [82], pyriproxyfen [83,84], diflubenzuron [85,86], buprofezin [84] and novaluron $[87,88]$. Addition of these chemicals to either animal bedding, old animal feeding sites, or any larval developmental substrate significantly reduced adult eclosion [89]. The earliest tests using 
insect growth regulators against stable flies (with juvenile hormone activity) were performed in the 1970s [90-97].

Injection of IGRs into animals such that their urine excretes residues of the drug onto their bedding was also an effective method of control [98]. Application of diflubenzuron to adult resting surfaces in intensive animal production [85] imposed ovicidal impacts on female stable flies, whereby egg hatch was reduced and subsequent development to adult flies inhibited [99]. Bedding from dairy cattle given a bolus of diflubenzuron inhibited stable fly development [100]. Cyromazine, applied as granules to old hay feeding sites, restricted adult stable fly development by $\leq 97 \%$ for up to 10 weeks post-application [101]. Similarly, cyromazine applied as granules to cattle, swine and poultry manure prevented stable fly development for up to 4 weeks post-application [82]. Novaluron applied as granules to cattle feeding sites that contained waste forage, manure, and urine suppressed adult stable fly development by $80 \%-90 \%$ for up to 12 weeks post-application [88]. Recent testing of stable flies across dairy farms in Germany did not show any signs of resistance to the insect growth regulators cyromazine and pyriproxyfen [65].

\subsection{Automatic Sprayers, Backrubbers and Ear Tags}

Treatment of animals directly with pesticides involves the use of automatic sprayers [102,103], backrubbers [104-106] or insecticide-impregnated ear tags. Excellent control of biting flies was noted with the use of an automatic cattle sprayer, where a small amount of concentrated insecticide $(0.2-1.7 \%$ pyrethrin) was applied to cattle when they stepped on a hinged platform while going to or from the milking barn or to feed and drink while in pastures [103]. Backrubbers as a method of insecticide application onto cattle was first released by the South Dakota State College Agricultural Experiment Station in the annual reports of 1950 and 1951 [107]. Cable-type back rubbers, soaked with a 5\% oil solution of DDT, have been used to control horn flies on rangeland cattle [107]. Due to the effort and cost involved in rounding up cattle, backrubbers were a simpler and cheaper treatment option. Insecticide-soaked burlap sacks were wrapped around a cable slung between two posts that sagged below the height of the animal's backline in areas where the animals often congregate. Without coercion, the animals walking underneath get a dose of insecticide along their back [106]. Although originally proposed for horn fly control, their use has assisted in efforts to manage stable flies [107].

Several insecticide compounds have been impregnated into plastic ear tags for use in cattle herds as a means of repelling and/or reducing stable flies that attempt to blood feed from the animals. Ear tags containing organophosphate (fenthion) and pyrethroid (flucythrinate, fenvalerate) insecticides have been used in the past with some success (10 weeks control on cattle [58]), limited success [108] and/or no success in reducing the stable fly burden on cattle [109].

\subsection{Repellents}

The use of repellents has become one of the most efficient ways to prevent discomfort associated with insect bites [110]. In 1985, an olfactometer was developed to improve measurement of repellency of chemicals to stable flies [111]. DEET (N,N-diethyl-meta-toluamide) developed in 1944, is considered by many as the gold standard of insect repellents [112]. First used by the military during World War II, DEET became the most extensively used personal arthropod repellent for over 50 years, with a particular focus on repelling mosquitoes. Hundreds of natural products including plant essential oils have been reported demonstrating their insecticidal and repellent properties [113-115]. However, nearly all plant-based repellents derived from plant essential oils have limited residual activity $(<4$ h) [116], primarily due to their high volatility. For example, citronella oil was the first successful plant-based insect repellent, but its effectiveness was limited to only several hours. DEET ( $>25 \%$ ) provides up to $10 \mathrm{~h}$ of protection against mosquitoes [117]. 


\subsubsection{Repellents on Livestock}

Reports on repellents to protect livestock from stable flies first appeared in the 1910s [118,119]. The earliest studies on repelling stable flies from cattle suggested the use of crank case oil and oil of tar as being the most promising results in terms of cost effectiveness and practicality [120]. Repellents specific to stable flies were reported in several studies in the 1940s and 1950s [121-124]. Most repellent formulations, however, have only demonstrated at best 1 to $2 \mathrm{~d}$ reprieve for animals [32,125], and with many less than $12 \mathrm{~h}$ of measurable reduction in stable flies [126].

Several essential oils (plant-derived) have been used as repellents against stable flies (e.g., catnip, peppermint, eucalyptus and lemongrass) [127-132] but again the repellency only lasts 1-2 $\mathrm{d}$. A repellent oil combination of sunflower $(95 \%)$, geranium $(2.5 \%)$ and lemongrass $(2.5 \%)$ applied to dairy cattle reduced both stable flies on the animals and fly defensive behaviors [133]. DEET has been added to numerous products for fly control to improve the repellency of biting flies. A combination of fipronil and permethrin worked well as a toxicant and repellent towards stable flies on dogs [134]. Research into fatty acids derived from coconut oil has shown excellent repellency to stable flies [135-137] with up to 2 weeks repellency being demonstrated in laboratory bioassays, and up to $96 \mathrm{~h}$ protection when applied to cattle in the field [138].

\subsubsection{Repellents on Humans}

The use of topical repellents to stable flies for humans was assessed by Gilbert et al. [139] where 4-pentyl-2-oxetanone was more repellent than DEET. Diethylphenyl-acetamide was identified as a new and safe repellent of stable flies when tested on rabbits [140], with its use then proposed for humans. Personal protective equipment to reduce the impact of biting flies (including stable flies) for both military [141] and civilian personnel typically involve rinsing or impregnating clothing with permethrin [142-144].

\section{Biological Control}

\subsection{Natural Predators of Stable Flies}

Since the last reviews of natural enemies of stable flies [145,146], there have been numerous papers on predators of stable flies, either from naturally occurring larvae and pupae and/or sentinel pupae set up in intensive livestock production areas. Smith et al. [147] noted that field mortality of stable flies was due to predation in their larval development sites. Hall et al. [148] found 19 arthropod species in five families to be predaceous as immatures or adults, in association with stable fly immatures developing in grass clippings in central Missouri, US. This study indicated that between $34 \%$ and $73 \%$ of apparent mortality was due to predation of stable fly eggs and larvae. Wasp parasitism in the field was as high as $13 \%-20 \%$ for stable fly and house fly pupae in Californian dairies [149], 10.6\% of stable fly pupae from cattle feedlots [150] and 10\% of stable fly pupae from Danish dairy farms [151]. All natural predators of stable flies recorded in the literature are listed in Table 1 (hymenopteran parasites) and Table 2 (non-hymenopteran insect predators). 
Table 1. Natural hymenopteran parasites of Stomoxys calcitrans recorded in the literature.

\begin{tabular}{lcc}
\hline Hymenoptera (Wasps) & Family & Reference \\
\hline Muscidifurax raptor Girault and Sanders & Pteromalidae & {$[146,152]$} \\
Muscidifurax zaraptor Kogan and Legner & Pteromalidae & {$[146,152]$} \\
Pachycrepoideus vindemiae Rondani & Pteromalidae & {$[152]$} \\
Spalangia cameroni Perkins & Pteromalidae & {$[149,153,154]$} \\
Spalangia drosophilae Ashmead & Pteromalidae & {$[155]$} \\
Spalangia endius Walker & Pteromalidae & {$[149,150]$} \\
Spalangia haematobiae Ashmead & Pteromalidae & {$[152,156]$} \\
Spalangia nigra Latrielle & Pteromalidae & {$[157]$} \\
Spalangia nigroaena Curtis & Pteromalidae & {$[150,158]$} \\
Spalangia subpunctata Förster & Pteromalidae & {$[152]$} \\
Trichomalopsis dubius Ashmead & Pteromalidae & {$[159]$} \\
Trichomalopsis viridescens Walsh & Pteromalidae & {$[152]$} \\
Urolepis rufipes Ashmead & Pteromalidae & {$[160-162]$} \\
Nasonia vitripennis Walker & Pteromalidae & {$[163]$} \\
Dibrachys cavus Walker & Pteromalidae & {$[159,161]$} \\
Aphaereta pallipes Say & Braconidae & {$[152,162]$} \\
Rubrica surinamensis DeGeer & Bembicidae & {$[164]$} \\
Diplazon laetatorius Fabricius & Ichneumonidae & {$[156]$} \\
Phygadeum fumator Gravenhörst & Ichneumonidae & {$[151,165]$} \\
Trichopria stomoxydis Huggert & Diapriidae & {$[166]$} \\
Trichopria spp. & Diapriidae & {$[167]$} \\
Coptera spp. & Diapriidae & {$[167]$} \\
\hline
\end{tabular}

By contrast, Floate et al. [161] found that $<1 \%$ of stable fly pupae in the field were parasitised. McKay and Galloway [165] found that 3.8\% of naturally occurring house fly and stable fly pupae were parasitised by nine different wasp species. Further, the authors concluded that releasing $>3.5$ million Nasonia vitripennis wasps did not result in substantial parasitism in either sentinel pupae or naturally occurring pupae of both fly species. Many other studies have found natural parasitism rates below $5 \%[150,160,162]$ and most often less than $1 \%[149,151-153,165]$. Total filth fly parasitism of natural pupae collected from cattle feedlots in Alberta, Canada did not exceed 7\% [168].

\subsubsection{Wasps}

The Pteromalidae family of wasps are only $2-3 \mathrm{~mm}$ in size [169] and harmless to humans and livestock. However, many are insect parasitoids and several species are important biological control agents of pest insects, in particular filth fly species associated with intensive animal production. The adult wasp lays one or more eggs on the surface of the fly pupa inside and the developing wasps kill the host fly. Fly parasitoid wasps associated with livestock production in North America have been widely studied, including species in the genera Muscidifurax, Spalangia, Trichomalopsis, Nasonia, Urolepis and Pachycrepoideus. Within and between each genera, there are differing habitat choice, host choice, and behavior. Some wasp species live gregariously as larvae within a host puparium, while most species are solitary as immatures. Similarly, some species prefer constantly wet habitats such as manure, whereas others prefer drier areas such as manure-soiled straw bedding. The abundance and habitat preference of each parasitoid species can differ between regions and seasons. 
Table 2. Natural non-hymenopteran insect predators of $S$. calcitrans recorded in the literature.

\begin{tabular}{llc}
\hline & Family & Reference \\
\hline Coleoptera (Beetles) & & \\
Aleochara bilineata Gyllenhal & Staphylinidae & {$[170]$} \\
Aleochara bimaculata Gravenhörst & Staphylinidae & {$[171]$} \\
Aleochara lacertina Sharp & Staphylinidae & {$[158,171]$} \\
Aleochara puberula Klug & Staphylinidae & {$[172]$} \\
Belonuchus rufipennis Fabricius & Staphylinidae & {$[145]$} \\
Lithocaris ardenus Sanderson & Staphylinidae & {$[145]$} \\
Oxytelus sculptus Gravenhörst & Staphylinidae & {$[158]$} \\
Philonthus americanus Erichson & Staphylinidae & {$[158]$} \\
Philonthus brunneus Gravenhörst & Staphylinidae & {$[145]$} \\
Philonthus hepaticus Erichson & Staphylinidae & {$[145]$} \\
Philonthus rectanguulus Sharp & Staphylinidae & {$[145]$} \\
Philonthus sericans Gravenhörst & Staphylinidae & {$[145]$} \\
Philonthus theveneti Horn & Staphylinidae & {$[173]$} \\
Staphylinus maculosus Gravenhörst & Staphylinidae & {$[145]$} \\
Acarina (Mites) & & \\
Macrocheles muscaedomesticae Scopoli & Machrochelidae & {$[146,174]$} \\
Macrocheles subbadius Berlese & Machrochelidae & {$[175]$} \\
\hline
\end{tabular}

\subsubsection{Staphylinids}

Staphylinidae beetles appear almost wingless and are known to predate on fly eggs and larvae in association with either cadavers or rotting plant material [176-178]. Smith et al. [146] noted that field mortality of stable flies was principally due to predation by staphylinid beetles. Staphylinids have been claimed to suppress biting fly populations (including mosquitoes) by Frank and Thomas [179], but without any supporting evidence. Staphylinids recorded in the literature as predators of stable flies are listed in Table 2. Aleochara species were found parasitising filth fly pupae in Kansas [171], but $<0.8 \%$ of 22,000 stable fly pupae collected from cattle feedlots produced any adult beetles (mostly Aleochara lacertina and some Aleochara bimaculata). Similarly, Aleochara puberula only emerged from 1\% of stable fly pupae in Brazil [172].

The author has seen staphylinid beetles (Aleochara spp.) feeding on stable fly eggs in rotting celery residues left after harvest near Perth, Western Australia. Adults and larvae of some Philonthus species occur in dung of ungulates and eat fly eggs and larvae [179]. When grass clippings were used as an artificial breeding medium for stable flies, the staphylinds Philonthus americanus and Oxytelus sculptus were the most abundant insect predators [158].

\subsubsection{Mites}

Mites were first touted as a biocontrol agent of synanthropic flies by Axtell [180]. Only two studies have looked at predation on stable fly eggs by mites. Macrocheles muscaedomesticae (Acarina: Macrochelidae) had negligible impact on stable flies in Kinn [174], despite it being noted that this mite was the most consistent and abundant predator to arrive early at sentinel, wet, ryegrass clippings seeded with laboratory-reared stable fly eggs [146]. Macrocheles embersoni was the best predator out of three mite species assessed against stable fly eggs and larvae, consuming 24 larvae per day [181]. Stable flies carrying mites represent only $5 \%-10 \%$ of the population at dairy and beef farms, with the mites major effect being to limit their dispersal compared with mite-free stable flies [175].

\subsubsection{Nematodes}

In addition to the arthropod predators identified in Table 1, nematodes from the Mermithidae family were found predating on stable flies [145]. Entomopathogenic nematodes search for and locate their hosts by detecting products of excretion, $\mathrm{CO}_{2}$ levels and temperature gradients. When a host is located, they penetrate through natural openings (mouth, anus and spiracles) or actively penetrate 
through the cuticle [182]. They then migrate into the hemocoel of the host [183] where their symbiotic bacteria release toxins that kill the host [184]. Nematodes were first noted as infecting stable flies by Poinar and Boxler [185] and further examined under laboratory conditions [186]. The use of entomopathogenic nematodes to control stable flies developing at round bale feeding sites has been tested by Pierce [187], who found that nematodes in the genera Steinernema and Heterorhabditis all showed efficacy against stable fly larvae. The commercially available strain Steinernema feltiae produced the highest mortality in stable flies (56\%) in laboratory bioassays on a hay/manure substrate [187]. Leal et al. [182] demonstrated that Heterorhabditis spp. of nematodes show potential against stable fly larvae, but they have not been used in any commercial context to control stable flies to date.

\subsubsection{Microsporidia}

Microsporidia are spore-forming unicellular parasites that were considered protozoans or protists, but are now known to be fungi, or a sister group to fungi. Stable flies were not susceptible to the microsporidian parasite Octosporea muscae domesticae [188].

\subsection{Commercially Available Predators used to Control Stable Flies}

A number of commercially available parasitic wasps have been used against stable flies, mostly in intensive animal industry settings and/or animal stables. Augmentative biological control of filth flies has become a commonly used technique for fly control on equine facilities [189], cattle feedlots [190] and poultry production [191]. Given suitable habitats and hosts, commercially available pupal parasitoids have the potential to suppress populations of filth flies. Studies on livestock facilities with various species of wasp have yielded mixed results, with suppression of fly populations from augmentative releases of parasitoids in some situations [192-198] and failures in others [165,199-203].

Releases of $S$. endius on cattle feedlots over 13 weeks did not significantly increase parasitism of stable fly pupae [204]. The fly pupal parasitoids M. raptor, M. zaraptor and S. nigroaenea from commercial insectaries failed to significantly reduce stable fly numbers despite weekly releases of high numbers at a cattle feedlot and dairy $[199,202]$. Weekly releases of S. nigroaenea over 4 months for 3 years on cattle feedlots in Illinois, US increased stable fly mortality [203]. In pig premises in Norway, bi-weekly releases of S. cameroni suppressed stable flies [205]. Weekly releases of S. cameroni on dairy and pig farms in Denmark did not affect stable fly numbers [198], whereas bi-weekly releases of the same wasp on dairy farms in Denmark did suppress stable fly numbers on cattle [206] and on one of two pig farms in a study conducted in Norway [205].

These contradictory results may be partially attributed to environmental factors that affected parasitoid abundance and distribution [198]. Study specific factors such as the use of insecticides, the use of low-quality commercial colonies, parasitoid microhabitat preferences, the availability of hosts, methods of release and timing of release may have also affected their effectiveness [207,208]. In addition, it is possible that existing parasitoid populations may inhibit the establishment or function of newly released species in augmentation programs [209]. Quarles [210] suggested that the success of a biological control program using pupal parasitoids relies on matching the released species with the climate and habitat of the release location, most appropriately by deploying endemic species.

\subsection{Biopesticides}

\subsubsection{Plant-derived Products}

Many plant-derived products with insecticidal activity against stable flies have been found. The first example in the literature was when $>70 \%$ of stable fly larvae died when reared on media containing 800 ppm of L-canavanine. This compound is a non-proteinogenic amino acid found in some legumes that acts as a toxin in the plant to protect against insect attack [211]. A soybean trypsin inhibitor was encapsulated in bovine red blood cells and fed to adult stable flies, resulting in $50 \%$ mortality and elimination of egg production [212]. The plant flavonoid pinocembrine exhibits larvicidal 
activity against stable flies [213], whilst extracts from Chaste tree seeds (Vitex agnus castus) effectively repelled biting flies for $\approx 6 \mathrm{~h}$ [214]. An extract from Melinis minutiflora grass also had pesticidal activity against stable fly adults and larvae [215].

\subsubsection{Semiochemicals}

Semiochemicals are signalling compounds that carry information between individuals of a species and cause a change in their behavior such as attraction or repellency [216]. Semiochemicals have proved to be highly potent insecticides against stable flies. Compounds such as rosalva, citronellol, geranyl acetone [217], beta-damascone, cyclemone A and melafleur [218] show remarkable toxicity to stable flies in both the laboratory and under field conditions.

\subsubsection{Entomopathogenic Fungi}

Entomopathogenic fungi are part of the decomposer community and inhabit soils where many filth fly species spend most of their life as mobile larvae or dormant pupae. Many fungi have developed the ability to invade different life history stages of flies, and in doing so, use the insect host to complete their life cycle. In a 2007 review by Wraight et al. [219], there were $>700$ species of fungi that were lethal to insects (i.e., entomopathogenic). Most of the important entomopathogenic fungi produce asexual non-motile spores or conidia, which are capable of surviving for long periods (1-5 yrs) during unfavourable environmental conditions (typically drought). Under favourable conditions, the conidia become infective units, which contact, germinate and pentrate the insect cuticle where they invade the hosts body to later release spores when the insect dies. The use of entomopathogenic fungi against stable flies represents an opportunity to deal with a serious pest of livestock and humans by biological means as compared with chemical intervention.

Examples of specific entomopathogenic fungi impacting stable flies include Metarhizium anisopliae, Metarhizium brunneum, Lecanicillium lecanii (formerly Verticillium lecanii), Beauvaria bassiana, Entomophthora muscae and Entomophthora schizophorae. Specifically, Moreas et al. [220] showed that a strain of M. anisopliae killed all stable fly eggs in a laboratory bioassay, but did not have any impact on larvae or pupae. This can be explained by the proven antimicrobial activity of stable fly larvae against other entomopathogenic fungi [221,222]. López-Sánchez et al. [223] showed that 7 days after exposure to isolates of M. anisopliae and B. bassiana collected from the soil of lodging pens of dairy production units, mortality of adult stable flies was $>90 \%$. Metarhizium brunneum was shown to significantly reduce stable fly oviposition when substrates were treated with two commercial fungal products [154]. González [224] suggested that accelerated decomposition of pineapple crop residues in Brazil could cause the material to be less attractive to female stable flies. Paganella-Chang [225], however, found that the rate of decomposition of pineapple stubble was not responsible for the control of stable flies, but rather the composition of the fungal decomposer community (i.e., Acremonium, Fusarium and Trichoderma spp.). Weeks et al. [226] demonstrated that commercial fungal agents containing M. anisopliae and B. bassiana induce mortality in adult stable flies.

Strains of B. bassiana have been used in several studies against larval and adult stable flies. Up to $90 \%$ mortality was demonstrated in adult stable flies exposed to B. bassiana [223]. Moreas et al. [227] showed pathogenicity of B. bassiana to immature stages of stable flies. Watson et al. [228] showed that B. bassiana helped control stable flies in the sawdust bedding in calf hutches, whilst Oliveira et al. [229] demonstrated the use of this fungus in controlling insect pests in poultry production. Verticillium lecanii and $V$. fusisporum were found to be pathogenic against stable flies where the fungus was found in adult populations in Denmark [230]. There are some fungi that clearly have species-specific effects on different nuisance flies. For example, $100 \%$ of house flies and only $2 \%$ of stable flies were susceptible to infection by E. muscae [231]. The fungus L. lecanii had no effect on immature stages of stable flies [232]. In Mexico, several applications of $M$. anisopliae formulations to cattle (4 times over 21 days) reduced stable fly numbers by $73 \%$ and reduced defensive fly behaviors by $\approx 67 \%$ [233]. 


\subsubsection{Entomopathogenic Bacteria}

Mortality was only induced in adult stable flies that fed on an isolate of Bacillus thuringiensis (thompsoni 4O1) and only when fed via blood or applied topically [234]. Similarly, Gingrich [235] showed that stable flies were the most resistant dipteran pest of cattle to $B$. thuringiensis when this bacterial agent was added to the feed of cattle.

\section{Sterile Insect Technique (SIT)}

The use of the Sterile Insect Technique against stable flies was only briefly pursued in the 1970s and early 1980s [236,237]. A feasibility study by LaBrecque et al. [238] into the release of sterile male stable flies to control wild population of stable flies on a small island $\left(218 \mathrm{~km}^{2}\right)$ in the Caribbean Sea (St. Croix, US Virgin Islands) showed that control was possible during the dry season using the mass rearing and sterilization outlined in Williams et al. [239]. Patterson et al. [240] reported that after 1 y of releasing 0.5 million sterile males each week on St. Croix, the wild population of stable flies across the island was reduced by $99.9 \%$.

The traditional SIT method utilizing irradiation has not been pursued further for controlling stable flies due to three key aspects of this pest's biology outlined in Taylor [4] and summarised here. Firstly, both sexes blood-feed several times per day, so any release of flies would significantly increase the impact on livestock nearby; secondly, stable flies disperse over a great distance, meaning that very high numbers would need to be released to affect control. Finally, stable fly outbreaks can rapidly develop due to their ability to exploit numerous substrates for larval development and their high reproductive rate.

\section{Physical Control}

\subsection{Trapping}

Stable fly trapping systems to catch and remove stable flies from areas where they are seriously affecting livestock (e.g., barns, stables, stalls, water troughs) form a large part of physical control. The first recorded trap for catching stable flies was by Hodge [241], where a large trap was fitted into a stable window and all other windows into the stable were covered. The trap had no bait and relied on the attraction of adult stable flies to the light coming through the trap apparatus. Over 4 months, this trap caught $\approx 4.3 \mathrm{~L}$ of stable flies (number unknown). The use of fly traps was outlined by Bishopp [242] for attracting and catching houseflies, blowflies and stable flies. Early versions of stable fly traps consisted of either emergence, animal-baited [243] or box-type traps with shingles or panels coated with an adhesive [244,245].

\subsubsection{Surveillance/Monitoring Traps}

Two key traps for monitoring stable flies have been subsequently modified and expanded upon: (1) the Williams trap using panels of the fiberglass product Alsynite [246] and (2) the use of Alsynite in cylindrical traps [247-250]. Clear fiberglass and ultraviolet reflectors are the most efficient material for trapping stable flies, especially when exposed in full sunlight [251]. The attractiveness of the spectral properties of Alsynite to stable flies was verified by Agee and Patterson [251]. More recently, plastic sheeting in the form of Coroplast ${ }^{\circledR}$ (Great Pacific Enterprises., Granby, Quebec, Canada) and polyethylene terphthalate have been shown to be more attractive to stable flies than Alsynite $[20,252]$.

\subsubsection{Electrocutor Traps}

The first use of an electrified grid was reported by Wells [253], where its use against stable flies was only loosely reported in a minor experiment with no fly counts given. Electrocutor grids re-appeared in the 1970s, with Morgan et al. [243] showing that they caught three times as many female stable flies as cage traps. Shreck et al. [254] showed that in combination with carbon dioxide, electrocutor grids 
were a highly selective, stable fly killer. A solar-powered electrocuting grid killed 4000 and 1200 stable flies/day in two studies $[255,256]$. One negative aspect of electrocuting insect traps is that they can release bacterial pathogens into the air such as Serratia marcescens and Escherichia coli and potentially spread infectious disease agents [257].

\subsubsection{Walk-Through Traps for Livestock}

In 1930 Loughnan [258] first investigated the concept of a walk-through fly trap for cattle with biting flies (horn and stable flies) being dislodged by a brush of leaves and branches as they walked into a darkened and partitioned building. Although principally developed to remove horn flies, this trap was suggested by Segal [259] as being more effective against stable flies. Later Hall and Doisy [260] tested a more portable walk-through trap developed by Bruce [261] for horn fly control, which Hall and Doisy [260] considered was better suited to stable fly control. A vacuum device was added to a walk thought trap by Denning et al. [262], which sucked up horn flies off dairy cattle as well as stable flies. This trap however only removed on average 10 stable flies/animal/walk through event [262].

\subsubsection{Modification of other Biting Fly Traps}

Traps designed to catch other biting flies that bother livestock including tabanids and horn flies also caught stable flies whose numbers were often recorded [263-269]. These include the Nzi [266], Vavoua [270], and Manitoba horse fly trap [271]. Several standard traps have been modified in terms of their colour [272], contrast with the trap border [273], size, non-drying adhesive on the trap surface [272], and odour source [274]. Catch rates of stable flies improved using dry-ice baited traps that were developed for capturing mosquitoes [275-277]. Release of $\mathrm{CO}_{2}$ at $3 \mathrm{~L} / \mathrm{min}$ caught three times as many stable flies compared with no gas or carbon monoxide [278]. Dry ice and components of animals breath such as 1-octen-3-ol [279] and acetone [280] increased catches of Stomoxys spp. [264].

Pickens [281] provided a review of the different trap types and attractants developed to catch stable flies, including trap colour, orientation and design. The effect of trap colour and type of adherent on catches of stable flies were assessed by Ruff [282] with blue traps catching more flies. Variations on the Williams trap were tested by Scholl et al. [283]. Different coloured beach balls and plasticized corrugated boards were assessed on catching stable flies along Florida beaches $[284,285]$. The ideal configuration, size and colour of target traps for stable flies was assessed by Hogsette and Foil [286]. Of late, the Knight Stick Trap and Sticky Wraps have been shown to be useful in areas where animals are housed and/or where pesticides are not allowed [287,288].

\subsubsection{Comparative Trap Studies}

Broce [249] improved on the Alsynite trap by using a cylindrical design $(30 \mathrm{~cm}$ diameter $x 30$ cm high), which caught more stable flies/unit area than the Williams trap [249,250]. Most stable flies notably land on the side protected from the wind $[249,289]$. Taylor and Berkebile [20] compared six different stable fly traps where a prototype trap with multi-sided, clear plastic panels and coated in a non-drying glue was the most efficient at trapping stable flies. Alsynite cylinder traps caught four times the number of stable flies as blue-black cloth targets around cylindrical traps [290]. Both trap types reflect and refract ultraviolet light, which attracts stable flies. Studies comparing various traps in catching stable flies were conducted by Mihok et al. [264] and Gilles et al. [291].

\subsubsection{Toxic Traps}

The concept of an attractant trap surface, material (e.g., Alsynite) or fabric being used as a toxicant or control system for stable flies was first proposed by Meifert et al. [292] who suggested treating Williams trap panels with a synthetic pyrethroid. Using this system, the authors reported a reduction in the local population of stable flies by $\approx 85 \%$ after 1 weeks trapping (the trap units removed $>30 \%$ of the adult population/day). Tseng et al. [293] suggested wrapping the panels on a Williams trap with white yarn impregnated with permethrin, as most pesticides easily wash off the impervious fiberglass. 
When the yarn is wrapped in a continuous coil (1.3 cm apart), it maximised contact by stable flies. Field longevity of the permethrin-impregnated yarn was estimated at 6-8 weeks [294]. Extrapolation of this concept to cloth targets treated with pesticide was first suggested by Foil and Younger [295]. They demonstrated that six times more stable flies were attracted to cloth targets compared with Alsynite traps. Fabric targets treated with $0.1 \% \lambda$-cyhalothrin remained effective against a susceptible strain of stable flies for up to 3 months exposure in the field in the US [296]. A recent laboratory bioassay study in Brazil showed that when stable flies had 30s contact with fabric cloths impregnated with $1 \%$ fipronil all the flies were dead when assessed $24 \mathrm{~h}$ after exposure; stable flies had to contact fabric impregnated with $1 \%$ chlorpyrifos for $60 \mathrm{~s}$ for $>98 \%$ of flies to be dead $24 \mathrm{~h}$ later [297].

\subsubsection{Effective Stable Fly Control through Trapping}

Sticky traps, strips and ribbons have been used to monitor stable flies in different environments [298], but in terms of reducing their population numbers, there are few conclusive studies. One notable exception was by Rugg [299], where the Williams trap [246] was shown to reduce numbers of stable flies at a zoo in Australia by $79 \%$ after 1 week ( $26 \%$ of population removed/day). Similarly, Alsynite cylinder traps caught $80 \%$ of stable flies within a zoological park in the US compared with a blue-black cloth target trap modified into a cylindrical trap [290]. Pickens [281] reviewed the use of traps to suppress stable fly populations. Sticky pyramid traps [300] and pyramid traps treated with tralomethrin (SP) [301] reduced stable fly populations on dairy farms. Large sticky traps in dairy calf facilities reduced stable flies by $\approx 14,000$ flies/week, which producers felt kept the numbers at acceptable levels [302]. Tam et al. [303] found that sticky traps did not protect horses from stable fly blood feeding. Several studies have used trap counts of stable flies to model their population dynamics [304-306] where the effects of weather on capture of stable flies has been quantified [248,307].

\subsection{Physical Protection of Livestock}

Horse owners often put protective rugs, fly boots and face masks on their horses to reduce the numbers of stable flies being able to blood feed from their animals. The use of mesh leggings and leg bands as a physical barrier (non-insecticidal) to stable flies reduced foot stomps behavior in both horses [308] and dairy cows (only leggings tested) [309]. A recent and novel approach has seen the painting of black and white stripes on livestock such as cattle, which can reduce biting fly attacks (mostly stable flies) and associated fly-avoidance behaviors [310].

\subsection{Physical Barriers}

In vegetable production areas north of Perth, Western Australia, post-harvest residues can support the development of $>1000$ stable fly adults $/ \mathrm{m}^{2}$ [2]. A novel and pesticide-free approach to controlling stable flies in this setting was developed by Cook et al. [311], which involved the burial of post-harvest residues followed by the compaction of the sandy soil above the residues. This resulted in a hard crust forming in the sand, that newly-emerged stable flies could not dig their way through to emerge at the soil surface [311]. This non-chemical method of control provided benefits to vegetable producers, including the retention of organic matter from the residues, less soil wind erosion and no need for a pesticide application. The use of plastic covers on pineapple crop residues increased the rate of anaerobic decomposition of the residues and prevented stable flies from accessing the residues. With increasing time under plastic cover, the pineapple stubble attracted significantly less stable fly oviposition, decreasing from 2928 eggs $/ \mathrm{m}^{2}$ after 10 days cover to just $152 \mathrm{eggs} / \mathrm{m}^{2}$ after 30 days cover [312]. Within animal housing and dairies, air curtains produce a physical barrier to flies and can help to reduce their numbers on animals [313].

\section{Cultural Control}

Cultural controls are typically the oldest methods that have been used to manage insect pests. However, with the development of cheap synthetic pesticides, these controls were either abandoned or 
considered too costly compared to using pesticides [314]. Because cultural controls are preventative rather than curative, they are dependent on long-range planning and require a thorough understanding of the biology and ecology of the target pest. Cultural control against stable flies in this review examines all the hygiene and sanitation measures used to either remove or alter the substrates that stable fly larvae can develop within.

Greene [315] stated that sanitation by the removal of animal and plant residue to prevent fly development is the most important and first method of fly control to be used for fly reduction. This simple method of stable fly control remains highly relevant for intensive animal production and accumulation of rotting plant residues in horticultural production. Reducing stable flies and their effects on livestock without the use of pesticides was reviewed by Pickens et al. [316]. The major benefits of cultural control methods are less selection pressure for insecticide resistance and less chemical residues in the environment that may negatively impact beneficial, non-target organisms.

\subsection{Sanitation}

Regular sanitation schedules, where stable fly oviposition substrates and larval developmental sites are removed, have been shown to be effective in reducing stable fly adult populations [317320]. Bishopp [321] noted that stable fly numbers can be kept down by proper handling of stable refuse, either by stacking or otherwise disposing properly of any accumulations of straw or hay, especially adjacent to stables. These sanitation efforts remain highly relevant wherever stable flies continue to affect livestock and are often the simplest and cheapest method of stable fly control. Uncovered silage stacks encourage stable fly development [322], which when simply covered was shown to be an effective means of preventing stable flies breeding [323].

\subsection{Manure Amendments}

Moore et al. [324] reviewed chemical amendments that would prevent ammonia volatilization from poultry litter. Addition of organic acids to the bedding material used in meat chicken production reduces the litter's $\mathrm{pH}$ and prevents the release of ammonia, which is a general fly attractant and oviposition stimulant [325]. For example, incorporation of sodium bisulfate reduces ammonia levels and stable fly populations in horse barns and calf hutches [326,327]. Calcium cyanamide $(1 \%-2.5 \%$ $\mathrm{v} / \mathrm{v}$ ) and sodium bisulphate $(10 \%)$ reduced the numbers of stable flies that developed from raw poultry litter by as much as $99 \%-100 \%$ [328]. In addition, the high nitrogen fertiliser calcium cyanamide was highly toxic to stable fly larvae both in the laboratory [329] and in the field when applied to a medium consisting of feedlot and dairy barn waste [330].

\subsection{Animal Bedding}

Several bedding treatments and options have shown a reduction in the number of stable fly larvae developing in animal bedding as their manure and urine mixes in with the bedding material. For example, sawdust, wood chips and ground corncob bedding significantly reduced densities of stable fly larvae in calf hutches $[98,331]$. The authors suggest that the aforementioned substrates do not support stable fly larval development as they do not have a high moisture content, are not rich in organic matter and do not promote microbial activity $[98,331]$, which is essential for stable fly larval survival and development [332].

\section{Integrated Pest Management (IPM)}

IPM of stable flies in general promotes the use of surveillance and monitoring of stable fly numbers to guide the use of chemical, biological and cultural control options in such a way that pesticide use is minimised. This will (i) allow for the use of commercially available biological control agents, (ii) encourage beneficial insects and natural predators of stable flies, and (iii) reduce the selection pressure for resistance to insecticides. Sanitation or on-farm hygiene are the simplest methods to employ, which includes regular removal of animal manures and soiled animal bedding. In addition any piles of 
plant material that can rot and support the development of stable fly larvae need to be either removed, buried under at least $1 \mathrm{~m}$ of soil, or buried and the soil above the plant material compacted [311]. IPM plans rely on surveillance and monitoring of fly pests to enable the correct identification of the target pest species and Kaufman et al. [333] provides a list of common pest flies including stable flies in urban and rural environments. IPM in urban environments was promoted by Greene [315] using a range of chemical, cultural and mechanical methods to control both stable flies and house flies.

IPM programs are particularly useful in intensive animal industries (dairy, beef, swine, and poultry) [334] for nuisance fly control and some specifically for managing stable flies. Integrated control strategies have been promoted for stable fly control associated with poultry $[335,336]$, beef cattle [337,338] and dairy cattle [300,338-342]. IPM of stable flies requires an area-wide approach to its management as the adult flies can travel long distances and their larval developmental sites are "diverse, dispersed and often difficult to locate" in agroecosystems [4]. For example, a program to reduce stable flies developing in the agricultural areas of western Florida was initiated to reduce the large, migratory swarms of stable flies to beaches and holiday resorts in Florida, which damaged the local tourism industry [343].

\section{Conclusions}

This review represents a comprehensive overview of all chemical, biological and cultural control management strategies employed over more than a century against stable flies, a continuing global pest of livestock and humans. This paper should serve as a complete and exhaustive reference for entomologists, livestock producers and horticulturalists with any involvement in management of stable fly populations, either from a research or technical perspective.

Funding: Although Horticulture Innovation Australia did not specifically fund this publication, their financial support via VG12022 and VG15002 in conjunction with the Department of Primary Industries and Regional Development (formerly the Department of Agriculture and Food Western Australia) enabled me to accumulate the literature and resources needed to put this review paper together.

Acknowledgments: Thanks to my great helpers with all things stable fly in the laboratory and the field, namely Jeremy Lindsey, Rob Deyl, Ian McPharlin and Don Telfer.

Conflicts of Interest: The author declares no conflict of interest. The funders had no role in the design of the study; in the collection, analyses, or interpretation of data; in the writing of the manuscript, or in the decision to publish the results.

\section{References}

1. Broce, A.B.; Hogsette, J.A.; Paisley, S. Winter feeding sites of hay in round bales as major developmental sites of Stomoxys calcitrans (Diptera: Muscidae) in pastures in spring and summer. J. Econ. Entomol. 2005, 98, 2307-2312. [CrossRef] [PubMed]

2. Cook, D.F.; Dadour, I.R.; Voss, S.C. Management of stable fly and other nuisance flies breeding in rotting vegetable matter associated with horticultural crop production. Int. J. Pest Manag. 2011, 57, 315-320. [CrossRef]

3. Cook, D.F.; Telfer, D.V.; Lindsey, J.B.; Deyl, R.A. Substrates across horticultural and livestock industries that support the development of stable flies, Stomoxys calcitrans (Diptera: Muscidae). Austral. Entomol. 2018, 57, 344-348. [CrossRef]

4. Taylor, D.B. Area-wide management of stable flies. In Area-wide Integrated Management of Insect Pests, FAO/IAEA Division of Nuclear Techniques in Food and Agriculture, 3rd International Conference on the Area-wide Management of Insect Pests; International Atomic Energy Agency: Vienna, Austria, 2017.

5. Williston, S.W. A new cattle pest. Am. Nat. 1889, 23, 584-590. [CrossRef]

6. Beach, C.L.; Clark, A.B. Protecting cows from flies. Storr. Agric. Exp. Stn. 1904, 32, 5-14.

7. Mitzmain, M.B. The bionomics of Stomoxys calcitrans Linnaeus: A preliminary account. Philipp. J. Sci. 1913,8, $29-48$.

8. Mitzmain, M.B. Stomoxys calcitrans Linn. A note giving a summary of its life history. Public Health Rep. 1913, 28, 345-346. [CrossRef] 
9. Newstead, R. On the life-history of Stomoxys calcitrans, Linn. J. Econ. Biol. 1906, 1, 157-166.

10. Campbell, J.B.; Skoda, S.R.; Berkebile, D.R.; Boxler, D.J.; Thomas, G.D.; Adams, D.C.; Davis, R. Effects of stable flies (Diptera: Muscidae) on weight gains of grazing yearling cattle. J. Econ. Entomol. 2001, 94, 780-783. [CrossRef]

11. Catangui, M.A.; Campbell, J.B.; Thomas, G.D.; Boxler, D.J. Average daily gains of brahman-Crossbred and english $\times$ xxotic feeder heifers exposed to low, medium, and high levels of stable flies (Diptera: Muscidae). $J$. Econ. Entomol. 1993, 86, 1144-1150. [CrossRef]

12. Catangui, M.A.; Campbell, J.B.; Thomas, G.D.; Boxler, D.J. Calculating economic injury levels for stable flies (Diptera: Muscidae) on feeder heifers. J. Econ. Entomol. 1997, 90, 6-10. [CrossRef] [PubMed]

13. Mullens, B.A.; Lii, K.-S.; Mao, Y.; Meyer, J.A.; Peterson, N.G.; Szijj, C.E. Behavioural responses of dairy cattle to the stable fly, Stomoxys calcitrans, in an open field environment. Med. Vet. Entomol. 2006, 20, 122-137. [CrossRef] [PubMed]

14. Wieman, G.A.; Campbell, J.B.; Deshazer, J.A.; Berry, I.L. Effects of stable flies (Diptera: Muscidae) and heat stress on weight gain and feed efficiency of feeder cattle. J. Econ. Entomol. 1992, 85, 1835-1842. [CrossRef] [PubMed]

15. Vitela-Mendoza, I.; Cruz-Vázquez, C.; Solano-Vergara, J.; Orihuela-Trujillo, A. Relationship between serum cortisol concentration and defensive behavioral responses of dairy cows exposed to natural infestation by stable fly, Stomoxys calcitrans. J. Dairy Sci. 2016, 99, 9912-9916. [CrossRef]

16. Avant, S. Stable flies: Locating, controlling and assessing the damage they cause. Int. Pest Control 2013, 55, 74-75.

17. Taylor, D.B.; Moon, R.D.; Mark, D.R. Economic impact of stable flies (Diptera: Muscidae) on dairy and beef cattle production. J. Med. Entomol. 2012, 49, 198-209. [CrossRef]

18. Cook, D.F.; Dadour, I.R.; Keals, N.J. Stable fly, house fly (Diptera: Muscidae), and other nuisance fly development in poultry litter associated with horticultural crop production. J. Econ. Entomol. 1999, 92, 1352-1357. [CrossRef]

19. Newson, H.D. Arthropod problems in recreation areas. Annu. Rev. Entomol. 1977, 22, 333-353. [CrossRef]

20. Taylor, D.B.; Berkebile, D. Comparative efficiency of six stable fly (Diptera: Muscidae) traps. J. Econ. Entomol. 2006, 99, 1415-1419. [CrossRef] [PubMed]

21. Patra, G.; Behera, P.; Das, S.K.; Saikia, B.; Ghosh, S.; Biswas, P.; Kumar, A.; Alam, S.S.; Kawlni, L.; Lalnunpuia, C.; et al. Stomoxys calcitrans and its importance in livestock: A review. Int. J. Adv. Agric. Res. 2018, 6, 30-37.

22. Simmons, S.W.; Dove, W.E. Waste celery as a breeding medium for the stablefly or "dog fly," with suggestions for control. J. Econ. Entomol. 1942, 35, 709-715. [CrossRef]

23. Mount, G.A.; Gahan, J.B.; Lofgren, C.S. Evaluation of insecticides in the laboratory against adult and larval stable flies. J. Econ. Entomol. 1965, 58, 685-687. [CrossRef]

24. Mount, G.A.; Gahan, J.B.; Lofgren, C.S. Laboratory tests with promising insecticides for control of adult and larval stable flies. J. Econ. Entomol. 1967, 60, 1600-1602. [CrossRef] [PubMed]

25. Blume, R.R.; Matter, J.J.; Eschle, J.L. Biting flies (Diptera: Muscidae) on horses: Laboratory evaluation of five insecticides for control. J. Med. Entomol. 1973, 10, 596-598. [CrossRef]

26. Campbell, J.B.; Hermanussen, J.F. Efficacy of insecticides and methods of insecticidal application for control of stable flies in Nebraska. J. Econ. Entomol. 1971, 64, 1188-1190. [CrossRef]

27. Clements, B.W.; Rogers, A.J.; Thomas, W.E.; Swenson, W.N. Tests of insecticides applied by ultra low volume ground equipment for the control of adult stable flies, Stomoxys calcitrans (L.). Mosq. News 1977, 37, 43-45.

28. Gahan, J.B.; Wilson, H.G.; Keller, C.; Smith, C.N. Toxicity of insecticides to stable flies. Usda-Ars 1968, 27, 33-123.

29. Costa, L.G. Toxicology of pesticides: A brief history. In Toxicology of Pesticides; Costa, L.G., Galli, C.L., Murphy, S.D., Eds.; NATO ASI Series (Series H: Cell Biology); Springer: Berlin, Germany, 1987; pp. 1-10.

30. Cory, E.N.; Harns, H.G.; Anderson, W.H. Dust for control of flies on cattle. J. Econ. Entomol. 1936, 29, 331-335. [CrossRef]

31. Blakeslee, E.B. DDT as a barn spray in stable fly control. J. Econ. Entomol. 1944, 37, 134-135. [CrossRef]

32. Bruce, W.N.; Decker, G.C. Fly control and milk flow. J. Econ. Entomol. 1947, 40, 530-536. [CrossRef]

33. Blakeslee, E.B. DDT surface sprays for control of stablefly breeding in shore deposits of marine grass. J. Econ. Entomol. 1945, 38, 548-552. [CrossRef] [PubMed] 
34. Kramer, J.P. A Study of Possible DDT Resistance in Stomoxys calcitrans (L.), the Stable Fly. Ph. D. Thesis, University of Missouri, Columbia, MO, USA, 1952.

35. Somme, L. Control of stable flies by Dipterex on Norwegian farms. Nor. Ent. Tidsskr. 1959, 11, 16-19.

36. Stenersen, J.; Somme, L. Notes on cross-resistance and genetics of resistance to the DDT-group insecticides in the stable fly (Stomoxys calcitrans (L.) (Diptera). Nor. Ent. Tidsskr. 1963, 12, 113-117.

37. Sweetman, D.C. Comparative effectiveness of DDT and DDD for control of flies. J. Econ. Entomol. 1947, 40, 565-566. [CrossRef]

38. Martyniuk, C.J.; Feswick, A.; Spade, D.J.; Kroll, K.J.; Barber, D.S.; Denslow, N.D. Effects of acute dieldrin exposure on neurotransmitters and global gene transcription in largemouth bass (Micropterus salmoides) hypothalamus. Neurotoxicology 2010, 31, 356-366. [CrossRef]

39. Schoof, H.F.; Siverly, R.E.; Coffey, J.H. Dieldrin as a chemical control material on community fly control programs. J. Econ. Entomol. 1951, 44, 803-807. [CrossRef]

40. Johnston, L.; Blakeslee, T.E. Stable fly tolerance to residues of DDT, dieldrin, malathion and diazinon. J. Econ. Entomol. 1961, 54, 528-530. [CrossRef]

41. Cory, E.N. The protection of dairy cattle from flies. J. Econ. Entomol. 1917, 10, 111-114. [CrossRef]

42. Dove, W.E.; Simmons, S.W. Control of stablefly, or "dog Ffy," breeding in shore deposits of bay grasses. J. Econ. Entomol. 1942, 35, 582-589. [CrossRef]

43. Simmons, S.W.; Dove, W.E. Creosote oil with water for control of the stablefly, or "dog fly," in drifts of marine grasses. J. Econ. Entomol. 1942, 35, 589-592. [CrossRef]

44. Simmons, S.W.; Dove, W.E. Experimental use of gas condensate for the prevention of fly breeding. J. Econ. Entomol. 1945, 38, 23-25. [CrossRef]

45. DeFoliart, G.R. Preventive spraying schedules for dairy farm fly control. J. Econ. Entomol. 1963, 56, 649-654. [CrossRef]

46. Cheng, T.-H.; Frear, D.E.H.; Enos, H.F., Jr. Fly control in dairy barns sprayed with dimethoate and the determination of dimethoate residues in milk. J. Econ. Entomol. 1961, 54, 740-742. [CrossRef]

47. Fisher, E.H. A dairy-barn fogging method for fly control. J. Econ. Entomol. 1955, 48, 330. [CrossRef]

48. Morgan, N.O.; Sullivan, W.N.; Schechter, M.S. Micronized resmethrin dust for control of flies in dairy barns. J. Econ. Entomol. 1973, 66, 1281-1282. [CrossRef] [PubMed]

49. Eddy, G.W.; McGregor, W.S. Residual action of organic insecticides against stable flies. J. Econ. Entomol. 1949, 42, 547-548. [CrossRef]

50. Cheng, T.-H.; Hower, A.A.; Sprenkel, R.K. Oil-based and water-based ciodrin sprays for fly control on dairy cattle. J. Econ. Entomol. 1965, 58, 910-913. [CrossRef]

51. Campbell, J.B.; Raun, E.S. Aerial ULV and LV applications of insecticides for control of the stable fly and the horn fly. J. Econ. Entomol. 1971, 64, 1170-1173. [CrossRef]

52. Beard, J. DDT and human health. Sci. Total Environ. 2006, 355, 78-89. [CrossRef]

53. Turusoy, V.; Rakitsky, V.; Tomatis, L. Dichlorodiphenyltrichloroethane (DDT): Ubiquity, persistence, and risks. Env. Health Perspect. 2002, 110, 125-128. [CrossRef]

54. Granett, P.; Haynes, H.L. Use of cyclethrin in livestock sprays for control of flies. J. Econ. Entomol. 1955, 48, 409-412. [CrossRef]

55. Schmidt, C.D.; Matter, J.J.; Meurer, J.H.; Reeves, R.E.; Shelley, B.K. Evaluation of a synthetic pyrethroid for control of stable flies and horn flies on cattle. J. Econ. Entomol. 1976, 69, 484-486. [CrossRef] [PubMed]

56. Bailie, H.D.; Morgan, D.W.T. Field trials to assess the efficacy of permthrin for the control of flies on cattle. Vet. Rec. 1980, 106, 124-127. [CrossRef] [PubMed]

57. Morgan, D.W.T.; Bailie, H.D. A field trial to determine the effect of fly control using permethrin on milk yields in dairy cattle in the UK. Vet. Rec. 1980, 106, 121-123. [CrossRef]

58. Hogsette, J.A.; Ruff, J.P. Evaluation of flucythrinate- and fenvalerate-impregnated ear tags and permethrin ear tapes for fly (Diptera: Muscidae) control on beef and dairy cattle in northwest Florida. J. Econ. Entomol. 1986, 79, 152-157. [CrossRef]

59. Hogsette, J.A.; Ruff, J.P. Control of stable flies and horn flies (Diptera: Muscidae) with permethrin tapes applied to tails of beef and dairy cattle. J. Econ. Entomol. 1987, 80, 417-420. [CrossRef]

60. Cruz-Vázquez, C.; García-Vázquez, Z.; Fernández-Ruvalcaba, M.; George, J.E. Susceptibility of Stomoxys calcitrans (L.) to permethrin in dairy farms of Aguascalientes, Mexico. Vet. México 2005, 36, 485-490. 
61. Pitzer, J.B.; Kaufman, P.E.; Tenbroeck, S.H. Assessing permethrin resistance in the stable fly (Diptera: Muscidae) in Florida by using laboratory selections and field evaluations. J. Econ. Entomol. 2010, 103, 2258-2263. [CrossRef]

62. Salem, A.; Bouhsira, E.; Liénard, E.; Bousquet Melou, A.; Jacquite, P.; Farnc, M. Susceptibility of two European strains of Stomoxys calcitrans to cypermethrin, deltamethrin, fenvalerate, lambda-cyhalothrin, permethrin and phoxim. Int. J. Appl. Res. Vet. M. 2012, 10, 249-257.

63. Tainchum, K.; Shukri, S.; Duvallet, G.; Etienne, L.; Jacquiet, P. Phenotypic susceptibility to pyrethroids and organophosphate of wild Stomoxys calcitrans (Diptera: Muscidae) populations in southwestern France. Parasitol. Res. 2018, 17, 4027-4032. [CrossRef]

64. De Barros, A.T.M.; Rodrigues, V.D.; Cancado, P.H.D.; Domingues, L.N. Resistance of the stable fly, Stomoxys calcitrans (Diptera: Muscidae), to cypermethrin in outbreak areas in Midwestern Brazil. Rev. Bras. Parasitol. Vet. 2019, 28, 802-806. [CrossRef] [PubMed]

65. Reissert-Oppermann, S.; Bauer, B.; Steuber, S.; Clausen, P.-H. Insecticide resistance in stable flies (Stomoxys calcitrans) on dairy farms in Germany. Parasitol. Res. 2019, 118, 2499-2507. [CrossRef] [PubMed]

66. Hurd-Karrer, A.M.; Poos, F.W. Toxicity of selenium-containing plants to aphids. Science 1936, 84, 252. [CrossRef] [PubMed]

67. McGregor, W.S.; Bushland, R.C. Research on the use of systemic insecticides for the control of livestock pests. J. Econ. Entomol. 1956, 49, 86-88. [CrossRef]

68. Lindquist, A.W.; Knipling, E.F.; Jones, H.A.; Madden, A.H. Mortality of bedbugs on rabbits given oral dosages of DDT and pyrethrum. J. Econ. Entomol. 1944, 37, 127-128. [CrossRef]

69. Drummond, R.O. Laboratory screening tests of animal systemic insecticides. J. Econ. Entomol. 1958, 51, 425-427. [CrossRef]

70. Drummond, R.O. Preliminary evaluation of animal systemic insecticides. J. Econ. Entomol. 1960, 53, 1125-1127. [CrossRef]

71. Drummond, R.O. Further evaluation of animal systemic insecticides, 1961. J. Econ. Entomol. 1962, 55, 398-402. [CrossRef]

72. Drummond, R.O. Further evaluation of animal systemic insecticides, 1962. J. Econ. Entomol. 1963, 56, 831-834. [CrossRef]

73. Drummond, R.O. Further evaluation of animal systemic insecticides, 1963. J. Econ. Entomol. 1964, 57, 741-745. [CrossRef]

74. Drummond, R.O. Further evaluation of animal systemic insecticides, 1964. J. Econ. Entomol. 1965, 58, 773-776. [CrossRef] [PubMed]

75. Drummond, R.O. Further evaluation of animal systemic insecticides, 1965. J. Econ. Entomol. 1966, 59, 1049-1053. [CrossRef] [PubMed]

76. Drummond, R.O. Further evaluation of animal systemic insecticides, 1966. J. Econ. Entomol. 1967, 60, $733-737$. [CrossRef]

77. Drummond, R.O. Further evaluation of animal systemic insecticides, 1967. J. Econ. Entomol. 1968, 61, 1261-1264. [CrossRef]

78. Boisvenue, R.J.; Hair, J.A. Systemic activity of a benzimidazoline compound in cattle against ticks and biting flies. Vet. Parasitol. 1985, 17, 327-335. [CrossRef]

79. Floate, K.D.; Spooner, R.W.; Colwell, D.D. Larvicidal activity of endectocides against pest flies in the dung of treated cattle. Med. Vet. Entomol. 2001, 15, 117-120. [CrossRef]

80. Madsen, M.; Nielson, B.O.; Holter, P.; Pedersen, O.C.; Jespersen, J.B.; Jensen, K.M.V.; Nansen, P.; Grønvold, J. Treating cattle with ivermectin: Effects on the fauna and decomposition of dung pats. J. Appl. Ecol. 1990, 27, 1-5. [CrossRef]

81. O'Neill, M.P.; Holman, G.M.; Wright, J.E. $\beta$-ecdysone levels in pharate pupae of the stable fly, Stomoxys calcitrans and interaction with chitin inhibitor diflubenzuron. J. Insect Physiol. 1977, 23, 1243-1244. [CrossRef]

82. Donahue, W.A., Jr.; Showler, A.T.; Donahue, M.W.; Vinson, B.E.; Osbrink, W.L.A. Lethal effects of the insect growth regulator cyromazine against three species of filth flies, Musca domestica, Stomoxys calcitrans, and Fannia canicularis (Diptera: Muscidae) in cattle, swine, and chicken manure. J. Econ. Entomol. 2017, 110, 776-782. [CrossRef]

83. Bull, D.L.; Meola, R.W. Interactions of the insect growth regulator pyriproxyfen with immature and adult stages of the stable fly. Southwest. Entomol. 1994, 19, 257-263. 
84. Liu, S.S.; Li, A.Y.; Lohmeyer, K.H.; Perez De Leon, A.A. Effects of pyriproxyfen and buprofezin on immature development and reproduction in the stable fly. Med. Vet. Entomol. 2012, 26, 379-385. [CrossRef] [PubMed]

85. Wright, J.E.; Campbell, J.B.; Oehler, D.D.; Schugart, J. Stable fly: Control with diflubenzuron applied to adult resting surfaces in cattle feedlots. Southwest. Entomol. 1977, 2, 155-158.

86. Spates, G.E.; Wright, J.E. Residues of diflubenzuron applied topically to adult stable flies. J. Econ. Entomol. 1980, 73, 595-598. [CrossRef]

87. Lohmeyer, K.H.; Pound, J.M.; Yeater, K.M.; May, M.A. Efficacy of novaluron as a feed-through for control of immature horn flies, house flies, and stable flies (Diptera: Muscidae) developing in cow manure. J. Med. Entomol. 2014, 51, 873-877. [CrossRef] [PubMed]

88. Taylor, D.B.; Friesen, K.A.; Zhu, J.J. Stable fly control in cattle winter feeding sites with novaluron, 2013. Arthropod Manag. Tests 2014, 39, 1-3. [CrossRef]

89. Wright, J.E.; Campbell, J.B.; Hester, P. Hormones for control of livestock arthropods: Evaluation of two juvenile hormone analogues applied to breeding materials in small plot tests in Nebraska and Florida for control of the stable fly. Environ. Entomol. 1973, 2, 69-72. [CrossRef]

90. Wright, J.E. Insect growth regulators: Laboratory and field evaluations of Thompson-Hayward TH-6040 against the house fly and the stable fly. J. Econ. Entomol. 1974, 67, 746-747. [CrossRef]

91. Wright, J.E.; Jones, R.L. Insect growth regulators: Methoprene and Stauffer R-20458 in pupae of the stable fly from treated breeding medium. Environ. Contam. Toxicol. 1976, 5, 525-529. [CrossRef]

92. Wright, J.E.; Kaplanis, J.N. Ecdysones and ecdysone-analogues: Effects on fecundity of the stable fly, Stomoxys Calcitrans. Ann. Entomol. Soc. Am. 1970, 63, 622-623. [CrossRef]

93. Wright, J.E.; Schwarz, M. Juvenilizing activity of compounds related to the juvenile hormone against pupae of the stable fly. J. Econ. Entomol. 1972, 65, 1644-1647. [CrossRef]

94. Wright, J.E.; Spates, G.E. Biological evaluation of juvenile hormone compounds against pupae of the stable fly. Ag. Food Chem. 1971, 19, 289-290. [CrossRef] [PubMed]

95. Wright, J.E.; Spates, G.E. Penetration and persistence of an insect growth regulator in the pupa of the stable fly, Stomoxys calcitrans. J. Insect Physiol. 1975, 21, 801-805. [CrossRef]

96. Wright, J.E.; Spates, G.E. Reproductive inhibition activity of the insect growth regulator TH 6040 against the stable fly and the house fly: Effects on hatchability. J. Econ. Entomol. 1976, 69, 365-368. [CrossRef] [PubMed]

97. Wright, J.E.; Spates, G.E.; Schwarz, M. Insect growth regulator AI3-36206. Biological activity against Stomoxys calcitrans and Musca domestica and its environmental stability. J. Econ. Entomol. 1976, 69, 79-82. [CrossRef] [PubMed]

98. Schmidtmann, E.T.; Miller, R.W.; Muller, R. Effect of experimental bedding treatments on the density of immature Musca domestica and Stomoxys calcitrans (Diptera: Muscidae) in outdoor calf hutches. J. Econ. Entomol. 1989, 82, 1134-1139. [CrossRef]

99. Wright, J.E.; Spates, G.E.; Kunz, S.E. Diflubenzuron: Ovicidal activity against adult stable flies exposed to treated surfaces or to treated animals. Southwest. Entomol. 1978, 3, 5-13.

100. Miller, R.W. Inhibition of house flies and stable flies (Diptera: Muscidae) in field-spread dairy bedding from cattle treated with diflubenzuron boluses. J. Econ. Entomol. 1994, 87, 402-404. [CrossRef]

101. Taylor, D.B.; Friesen, K.; Zhu, J.J.; Sievert, K. Efficacy of cyromazine to control immature stable flies (Diptera: Muscidae) developing in winter hay feeding sites. J. Econ. Entomol. 2012, 105, 726-731. [CrossRef]

102. Berry, I.L.; Hoffman, R.A. Use of step-on switches for control of automatic sprayers. J. Econ. Entomol. 1963, 56, 888-890. [CrossRef]

103. Granett, P.; Hansens, E.J.; O'Connor, C.T. Automatic cattle sprayers for fly control in New Jersey. J. Econ. Entomol. 1955, 48, 386-389. [CrossRef]

104. Cheng, T.-H.; Vandervberg, J.P. The treadle sprayer and the cable-type back rubber for control of biting flies on cattle in Pennsylvania. J. Econ. Entomol. 1958, 51, 149-156. [CrossRef]

105. Raun, E.S.; Casey, D.J. A comparison of back rubber formulations for controlling horn and stable flies in Iowa. J. Econ. Entomol. 1956, 49, 395-397. [CrossRef]

106. Rogoff, W.M.; Moxon, A.L. Cable type back rubbers for horn fly control on cattle. J. Econ. Entomol. 1952, 45, 329-334. [CrossRef]

107. Rogoff, W.M. Cable-type backrubbers for horn fly control on cattle. Bulletins 1952, 418, 1-12. 
108. Harris, J.A.; Hillerton, J.E.; Morant, S.V. Effect on milk production of controlling muscid flies, and reducing fly-avoidance behaviour, by the use of fenvalerate ear tags during the dry periods. J. Dairy Res. 1987, 54, 165-171. [CrossRef]

109. Guglielmone, A.A.; Volpogni, M.M.; Quaino, O.R.; Anziani, O.S.; Mangold, A.J. Abundance of stable flies on heifers treated for control of horn flies with organophosphate impregnated ear tags. Med. Vet. Entomol. 2004, 18, 10-13. [CrossRef]

110. Fradin, M.S.; Gentile, D.A.; Lang, J.E. Protection from blood-feeding arthropods. In Wilderness Medicine, 4th ed.; Auerbach, P.S., Ed.; Mosby: St Louis, MO, USA, 2001; pp. 754-768.

111. Bartlett, C. An olfactometer for measuring the repellent effect of chemicals on the stable fly, Stomoxys calcitrans (L.). Pestic. Sci. 1985, 16, 479-487. [CrossRef]

112. Leal, W.S. The enigmatic reception of DEET - the gold standard of insect repellents. Curr. Opin. Insect Sci. 2014, 6, 93-98. [CrossRef]

113. Isman, M.B. Botanical insecticides, deterrents, and repellents in modern agriculture and an increasingly regulated world. Annu. Rev. Entomol. 2006, 51, 45-66. [CrossRef]

114. Nerio, L.S.; Olivero-Verbel, J.; Stashenko, E. Repellent activity of essential oils: A review. Bioresour. Technol. 2010, 101, 372-378. [CrossRef]

115. Thacker, J.R.M. An Introduction to Arthropod Pest Control; Cambridge University Press: Cambridge, UK, 2002.

116. Rehman, J.U.; Ali, A.; Khan, I.A. Plant based products: Use and development as repellents against mosquitoes: A review. Fitoterapia 2014, 95, 65-74. [CrossRef] [PubMed]

117. Lupi, E.; Hatz, C.; Schlagenhauf, P. The efficacy of repellents against Aedes, Anopheles, Culex and Ixodes spp. a literature review. Travel. Med. Infect. Dis. 2013, 11, 374-411. [CrossRef] [PubMed]

118. Baker, A.W. Preliminary notes on the use of repellents for horn flies and stable flies on cattle. Entomol. Soc. Ont. 1917, 36, 52-56.

119. Graybill, H.W. Repellents for protecting animals from the attacks of flies. Bull. Us Dept. Agric. 1914, $131,26$.

120. Cleveland, C.R. Repellent sprays for flies attacking dairy cattle. J. Econ. Entomol. 1926, 19, 529-536. [CrossRef]

121. Goodhue, L.D.; Stansbury, R.E. Some new fly repellents from laboratory screening tests. J. Econ. Entomol. 1953, 46, 982-985. [CrossRef]

122. Granett, P.; Haynes, H.L.; Connola, D.P.; Bowery, T.G.; Barber, G.W. Two butoxypolypropylene glycol compounds as fly repellents for livestock. J. Econ. Entomol. 1949, 42, 281-286. [CrossRef]

123. Granett, P.; Haynes, H.L.; Helm, R.W. Further evaluation of butoxypolypropylene glycol as a fly repellent for dairy cattle. J. Econ. Entomol. 1951, 44, 97-102. [CrossRef]

124. Howell, D.E.; Fenton, F.A. The repellency of a pyrethrum-thiocyanate oil spray to flies attacking cattle. J. Econ. Entomol. 1944, 37, 677-680. [CrossRef]

125. Bruce, W.N.; Decker, G.C. Experiments with several repellent formulations applied to cattle for the control of stable flies. J. Econ. Entomol. 1957, 50, 709-713. [CrossRef]

126. Cheng, T.-H.; Frear, D.E.H.; Enos, H.F., Jr. Effectiveness of aerosol formulations containing methoxychlor and other insecticide-repellents against biting flies on cattle, and analyses of milk from treated animals. J. Econ. Entomol. 1959, 52, 866-868. [CrossRef]

127. Baldacchino, F.; Tramut, C.; Aslem, A.; Liénard, E.; Delétré, E.; Franc, M.; Martin, T.; Duvallet, G.; Jay-Robert, P. The repellency of lemongrass oil against stable flies tested using video tracking. Parasite 2013, 20, 21. [CrossRef] [PubMed]

128. Hieu, T.T.; Kim, S.-I.; Kwon, H.W.; Ahn, Y.-J. Enhanced repellency of binary mixtures of Zanthoxylum piperitum pericarp steam distillate or Zanthoxylum armatum seed oil constituents and Calophyllum inophyllum nut oil and their aerosols to Stomoxys Calcitrans. Pest Manag. Sci. 2010, 66, 1191-1198. [CrossRef] [PubMed]

129. Khater, F.; Ramadan, M.Y.; El-Madawy, R.S. Lousicidal, ovicidal and repellent efficacy of some essential oils against lice and biting flies infesting water buffaloes in Egypt. Vet. Parasitol. 2009, 164, 257-266. [CrossRef] [PubMed]

130. Showler, A.T. Botanically based repellent and insecticidal effects against horn flies and stable flies (Diptera: Muscidae). J. Integr. Pest Manag. 2017, 8. [CrossRef]

131. Zhu, J.J.; Wienhold, B.J.; Wehrle, J.; Davis, D.; Chen, H.; Taylor, D.; Friesen, K.; Zurek, L. Efficacy and longevity of newly developed catnip oil microcapsules against stable fly oviposition and larval growth. Med. Vet. Entomol. 2014, 28, 222-227. [CrossRef] [PubMed] 
132. Zhu, J.J.; Zeng, X.-P.; Berkebile, D.; Du, H.-J.; Tong, Y.; Qian, K. Efficacy and safety of catnip (Nepeta cataria) as a novel filth fly repellent. Med. Vet. Entomol. 2009, 23, 209-216. [CrossRef]

133. Woolleya, C.E.; Lachanceb, S.; DeVriesa, T.J.; Bergerona, R. Behavioural and physiological responses to pest flies in pastured dairy cows treated with a natural repellent. Appl. Anim. Behav. Sci. 2018, 207, 1-7. [CrossRef]

134. Fankhauser, B.; Irwin, J.P.; Stone, M.L.; Chester, S.T.; Soll, M.D. Repellent and insecticidal efficacy of a new combination of fipronil and permethrin against stable flies (Stomoxys calcitrans). Parasite Vector 2015, 8, 6. [CrossRef]

135. Hieu, T.T.; Choi, W.S.; Kim, S.-I.; Wang, M.; Ahn, Y.-J. Enhanced repellency of binary mixtures of Calophyllum inophyllum nut oil fatty acids or their esters and three terpenoids to Stomoxys calcitrans. Pest Manag. Sci. 2015, 71, 1213-1218. [CrossRef]

136. Mullens, B.A.; Reifenrath, W.G.; Butler, S.M. Laboratory trials of fatty acids as repellents or antifeedants against houseflies, horn flies and stable flies (Diptera: Muscidae). Pest Manag. Sci. 2009, 65, 1360-1366. [CrossRef]

137. Roh, G.H.; Xiaaojie, Z.; Wang, Y.; Cermak, S.C.; Kenar, J.A.; Lehmann, A.; Han, B.; Taylor, D.B.; Zeng, X.; Park, C.G.; et al. Spatial repellency, antifeedant activity and toxicity of three medium chain fatty acids and their methyl esters of coconut fatty acid against stable flies. Pest Manag. Sci. 2020, 76, 405-414. [CrossRef] [PubMed]

138. Zhu, J.J.; Cermak, S.C.; Kenar, J.A.; Brewer, G.; Haynes, K.F.; Boxler, D.; Baker, P.D.; Wang, D.; Wang, C.; Li, A.Y.; et al. Better than DEET repellent compounds derived from coconut oil. Sci. Rep. 2018, 8, 1-12. [CrossRef] [PubMed]

139. Gilbert, I.H.; Gouck, H.K.; Schreck, C.E. Comparison of four cinchoninates, an oxetanone, and two standard skin repellents against Aedes aegypti and Stomoxys Calcitrans. Fla. Entomol. 1970, 53, 89-92. [CrossRef]

140. Parashar, B.D.; Gupta, G.P.; Sikder, N.; Rao, K.M. Diethylphenylacetamide: A new insect repellent against stable fly, Stomoxys calcitrans. Med. Vet. Entomol. 1993, 7, 259-262. [CrossRef]

141. Anon. Personal protective measures against insects and other arthropods of military significance. In Armed Forces Pest Management Board Technical Guide No. 36; The Armed Forces Pest Management Board, US Army Garrison-Forest Glen: Silver Spring, MD, USA, 2015.

142. Schreck, C.E.; Posey, K.; Smith, D. Durability of permethrin as a potential clothing treatment to protect against blood-feeding arthropods. J. Econ. Entomol. 1978, 71, 397-400. [CrossRef]

143. Schreck, C.E.; Smith, N.; Weidhaas, D.; Posey, K.; Smith, D. Repellents vs. toxicants as clothing treatments for protection from mosquitoes and other biting flies. J. Econ. Entomol. 1978, 71, 919-922. [CrossRef]

144. Schreck, C.E.; Weidhaas, D.E.; Smith, N.; Posey, K.H. Chemical treatment of wide-mesh net clothing for personal protection against blood feeding arthropods. Mosq. News 1977, 37, 455-462.

145. Smith, J.P.; Hall, R.D.; Thomas, G.D. Natural enemies of the stable fly, Stomoxys calcitrans (L.) and their impact in Missouri. J. Kans. Entomol. Soc. 1983, 56, 454-455.

146. Smith, J.P.; Hall, R.D.; Thomas, G.D. A review of natural mortality and enemies of the stable fly (Diptera: Muscidae) in Missouri. Fla. Entomol. 1989, 72, 351-360. [CrossRef]

147. Smith, J.P.; Hall, R.D.; Thomas, G.D. Field studies on mortality of the immature stages of the stable fly (Diptera: Muscidae). Environ. Entomol. 1985, 14, 881-890. [CrossRef]

148. Hall, R.D.; Smith, J.P.; Thomas, G.D. Effects of predatory arthropods on the survival of immature stable flies (Diptera: Muscidae) Misc. Publ. Entomol. Soc. Am. 1989, 74, 33-40.

149. Meyer, J.A.; Shultz, T.A.; Collar, C.; Mullens, B.A. Relative abundance of stable fly and house fly (Diptera: Muscidae) pupal parasites (Hymenoptera: Pteromalidae; Coleoptera: Staphylinidae) on confinement dairies in California. Environ. Entomol. 1991, 20, 915-921. [CrossRef]

150. Jones, C.J.; Weinzierl, R.A. Geographical and temporal variation in pteromalid (Hymenoptera: Pteromalidae) parasitism of stable fly and house fly (Diptera: Muscidae) pupae collected from Illinois cattle feedlots. Environ. Entomol. 1997, 26, 421-432. [CrossRef]

151. Skovgård, H.; Steenberg, T. Activity of pupal parasitoids of the stable fly Stomoxys calcitrans and prevalence of entomopathogenic fungi in the stable fly and house fly in Denmark. Biocontrol 2002, 47, 45-60. [CrossRef]

152. Gibson, G.; Floate, K.D. Filth fly parasitoids on dairy farms in Ontario and Quebec, Canada. Can. Entomol. 2004, 136, 407-417. [CrossRef] 
153. Greene, G.L.; Hogsette, J.A.; Patterson, R.S. Parasites that attack stable fly and house fly (Diptera: Muscidae) puparia during the winter on dairies in northwestern Florida. J. Econ. Entomol. 1989, 82, 412-415. [CrossRef]

154. Machtinger, E.T.; Weeks, E.N.I.; Geden, C.J. Oviposition deterrence and immature survival of filth flies (Diptera: Muscidae) when exposed to commercial fungal products. J. Insect Sci. 2016, 16, 1-6.

155. Floate, K.D.; Gibson, G.A.P. Filth fly parasitoids (Hymenoptera: Ptermomalidae) in North America. In Encyclopedia of Entomology; Capinera, J.L., Ed.; Springer Press: Dordrecht, The Netherlands, 2008.

156. Smith, J.P.; Hall, R.D.; Thomas, G.D. Field parasitism of the stable fly (Diptera: Muscidae). Ann. Entomol. Soc. Am. 1987, 80, 391-397. [CrossRef]

157. Legner, E.F.; Olton, G.S. Distribution and relative abundance of Dipterous pupae and their parasitoids in accumulations of domestic animal manure in the southwestern United States. Hilgardia 1971, 40, 505-535. [CrossRef]

158. Seymour, R.C.; Campbell, J.B. Predators and parasitoids of house flies and stable flies (Diptera: Muscidae) in cattle confinements in west central Nebraska. Environ. Entomol. 1993, 22, 212-219. [CrossRef]

159. Hoebeke, E.R.; Rutz, D.A. Trichomalopsis dubius (Ashmead) and Dibrachys cavus (Walker): Newly discovered pupal parasitoids (Hymenoptera: Pteromalidae) of house flies and stable flies associated with livestock manure. Ann. Entomol. Soc. Am. 1988, 81, 493-497. [CrossRef]

160. Petersen, J.J.; Guzman, D.R.; Pawson, B.M. Urolepis rufipes (Hymenoptera: Pteromalidae), a new parasite record for filth flies (Diptera: Muscidae) in Nebraska, USA. J. Med. Entomol. 1985, 22, 345. [CrossRef]

161. Floate, K.D.; Khan, B.; Gibson, G. Hymenopterous parasitoids of filth fly (Diptera: Muscidae) pupae in cattle feedlots. Can. Entomol. 1999, 131, 347-362. [CrossRef]

162. Noronha, C.; Gibson, G.A.P.; Floate, K.D. Hymenopterous parasitoids of house fly and stable fly puparia in Prince Edward Island and New Brunswick, Canada. Can. Entomol. 2007, 139, 748-750. [CrossRef]

163. Skovgård, H.; Jespersen, J.B. Activity and relative abundance of hymenopterous parasitoids that attack puparia of Musca domestica and Stomoxys calcitrans (Diptera: Muscidae) on confined pig and cattle farms in Denmark. Bull. Entomol. Res. 1990, 89, 263-269. [CrossRef]

164. Callan, E.M.C.C. A wasp preying on house flies and stable flies. Nature 1945, 155, 146. [CrossRef]

165. McKay, T.; Galloway, T.D. Biology of Phygadeum fumator Gravenhorst (Hymenoptera: Ichneumonidae) a pupal parasitoid of house and stable flies (Diptera: Muscidae) in Manitoba. Entomol. Soc. Manit. 1999, 55, $17-27$.

166. Morgan, P.B.; Hogsette, J.A.; Patterson, R.S. Life history of Trichopria stomoxydis (Hymenoptera: Proctotrupoidea: Diapriidae) a gregarious endoparasite of Stomoxys calcitrans from Zimbabwe, Africa. Fla. Entomol. 1990, 73, 496-502. [CrossRef]

167. Hogsette, J.A.; Farkas, R.; Coler, R.R. Hymenopteran pupal parasites recovered from house fly and stable fly (Diptera: Muscidae) pupae collected on livestock and poultry facilities in northern and central Hungary. Environ. Entomol. 1994, 23, 778-781. [CrossRef]

168. Lysyk, T.J. Parasitoids (Hymenoptera: Pteromalidae, Ichneumonidae) of filth fly (Diptera: Muscidae) pupae at dairies in Alberta. J. Econ. Entomol. 1995, 88, 659-665. [CrossRef]

169. Rueda, L.M.; Axtell, R.C. Guide to common species of pupal parasites (Hymenoptera: Pteromalidae) of the house fly and other muscoid flies associated with poultry and livestock manure. North Carol. Agric. Res. Serv. Tech. Bull. 1985, 278, 1-88.

170. Whistlecraft, J.W.; Harris, C.R.; Tolman, J.H.; Tomlin, A.D. Mass-rearing technique for Aleochara bilineata (Coleoptera: Staphylinidae). J. Econ. Entomol. 1985, 78, 995-997. [CrossRef]

171. Greene, G.L. Occurrence of Aleochara spp. (Coleoptera: Staphylinidae) parasitoidism of filth fly pupae in western Kansas. J. Kans. Entomol. Soc. 1997, 70, 70-72.

172. De Almeida, M.A.F.; Prado, A.P.D. Aleochara spp. (Coleoptera: Staphylinidae) and pupal parasitoids (Hymenoptera: Pteromalidae) attacking symbovine fly pupae (Diptera: Muscidae, Sarcophagidae and Otitidae) in southeastern Brazil. Biol. Control 1999, 14, 77-83. [CrossRef]

173. Campbell, J.B.; Hermanussen, J.F. Philonthus theveneti: Life history and predatory habits against stable flies, house flies, and face flies under laboratory conditions. Environ. Entomol. 1974, 3, 356-358. [CrossRef]

174. Kinn, D.N. Predation by the mite, Macrocheles muscae domesticae (Acarina: Macrochelidae), on three species of flies. J. Med. Entomol. 1966, 3, 155-158. [CrossRef] 
175. Beresford, D.V.; Sutcliffe, J.F. The effect of Macrocheles muscae domestica and M. subbadius (Acarina: Macrochelidae) phoresy on the dispersal of Stomoxys calcitrans (Diptera: Muscidae). Syst. Appl. Acarol. Spec. Publ. 2009, 23, 1-30.

176. Andersen, A.; Hansen, Å.G.; Rydland, N.; Øyre, G. Carabidae and Staphylinidae (Col.) as predators of eggs of the turnip root fly Delia floralis Fallén (Diptera, Anthomyiidae) in cage experiments. J. Appl. Entomol. 2009, 95, 499-506. [CrossRef]

177. Ferrar, P. A Guide to the Breeding Habits and Immature Stages of Diptera Cyclorrhapha. Part I: Text; Scandinavian Science Press: Copenhagen, DE, USA, 1987.

178. Watson-Horzelski, E.J. Survival and time of development for Creophilus maxillosus (L.) (Coleoptera: Staphylinidae) at three constant temperatures. Coleopts. Bull. 2012, 66, 365-370. [CrossRef]

179. Frank, J.H.; Thomas, M.C. Rove Beetles (Coleoptera: Staphylinidae). In Encyclopedia of Entomology, 2nd ed.; Capinera, J.L., Ed.; Springer-Verlag: Heidelberg, Germany, 2008; pp. 218-226.

180. Axtell, R.C. Macrochelidae (Acarina: Mesostigmata) as biological control agents fro synanthropic flies. Int. Congr. Acarol. 1967, 2, 401-416.

181. Azevedo, L.H.; Ferreira, M.P.; de Campos Castilho, R.; Cançado, P.H.D.; de Moraes, G.J. Potential of Macrocheles species (Acari: Mesostigmata: Macrochelidae) as control agents of harmful flies (Diptera) and biology of Macrocheles embersoni Azevedo, Castilho and Berto on Stomoxys calcitrans (L.) and Musca domestica L. (Diptera: Muscidae). 2018, 123, 1-8.

182. Leal, L.C.S.R.; Monteiro, C.M.O.; de Mendonça, A.E.; Bittencourt, V.R.E.P.; Bittencourt, A.J. Potential of entomopathogenic nematodes of the genus Heterorhabditis for the control of Stomoxys calcitrans (Diptera: Muscidae). Rev. Bras. Parasitol. V. 2017, 26, 451-456. [CrossRef] [PubMed]

183. Kaya, H.K.; Gaugler, R. Entomopathogenic nematodes. Annu. Rev. Entomol. 1993, 38, 181-206. [CrossRef]

184. Hazir, S.; Kaya, H.K.; Stock, P.; Keskin, N. Entomopathogenic nematodes (Steinernematidae and Heterorhabditidae) for biological control of soil pests. Turk. J. Biol. 2003, 27, 181-202.

185. Poinar, G.O., Jr.; Boxler, D.J. Infection of Stomoxys calcitrans (Diptera) by neoaplectanid nematodes (Steinernematidae). IRCS Med. Sci. 1984, 12, 481.

186. Mahmoud, M.F.; Mandour, N.S.; Pomazkov, Y.I. Efficacy of the entomopathogenic nematode Steinernema feltiae cross N 33 against larvae and pupae of four fly species in the laboratory. Nematol. Mediterr. 2007, 35, 221-226.

187. Pierce, L.R. Efficacy of Entomopathogenic Nematodes Utilized for Control of Stable Flies (Stomoxys calcitrans) at Round Bale Feeding Sites. Ph.D. Thesis, Oklahoma State University, Stillwater, OK, USA, 2012.

188. Kramer, J.P. Susceptibility of sixteen species of Muscoid flies to the microsporidian parasite Octosporea Muscae Domest. J. New York Entomol. Soc. 1973, 81, 50-53.

189. Machtinger, E.T.; Geden, C.J.; Kaufman, P.E.; House, M.A. Use of pupal parasitoids as biological control agents of filth flies on equine facilities. J. Integr. Pest Manag. 2015, 6, 1-10. [CrossRef]

190. Greene, G.L.; Cilek, J.E. Management of stable flies in cattle feedlots with releases of parasitic wasps. Cattlemen's Day. Kans. State Univ. Agric. Exp. Stn. Coop. Ext. Serv. 1993, 58. [CrossRef]

191. Pinnock, D.E.; Mullens, B.A. Application and evaluation of entomopathogens for control of livestock and poultry pests. In Field Manual of Techniques in Invertebrate Pathology; Lacey, L.A., Kaya, H.K., Eds.; Chapter VII-21; Springer: Dordrecht, The Netherlands, 2007; pp. 713-734.

192. Crespo, D.C.; Lecuona, E.E.; Hogsette, J.A. Biological control: An important component in integrated management of Musca domestica (Diptera: Muscidae) in caged-layer poultry houses in Buenos Aires, Argentina. Biol. Control 1998, 13, 16-24. [CrossRef]

193. Crespo, D.C.; Lecuona, E.E.; Hogsette, J.A. Strategies for controlling house fly populations resistant to cyromazine. Neotrop. Entomol. 2002, 31, 141-147. [CrossRef]

194. Geden, C.J.; Hogsette, J.A. Suppression of house flies (Diptera: Muscidae) in Florida poultry houses by sustained releases of Muscidifurax raptorellus and Spalangia cameroni (Hymenoptera: Pteromalidae). Environ. Entomol. 2006, 35, 75-82. [CrossRef]

195. Morgan, P.B. Sustained releases of Spalangia endius Walker (Hymenoptera: Pteromalidae) for the control of Musca domestica and Stomoxys calcitrans (Diptera: Muscidae). J. Kans. Entomol. Soc. 1980, 53, 367-372.

196. Morgan, P.B.; Patterson, R.S. Sustained releases of Spalangia endius to parasitize field populations of three species of filth breeding flies. J. Econ. Entomol. 1977, 70, 450-452. [CrossRef] [PubMed] 
197. Petersen, J.J.; Cawthra, J.K. Release of a gregarious Muscidifurax species (Hymenoptera: Pteromalidae) for the control of filth flies associated with confined beef cattle. Biol. Control 1995, 5, 279-284. [CrossRef]

198. Skovgård, H.; Nachman, G. Biological control of house flies Musca domestica and stable flies Stomoxys calcitrans (Diptera: Muscidae) by means of inundative releases of Spalangia cameroni (Hymenoptera: Pteromalidae). Bull. Entomol. Res. 2004, 94, 555-567. [CrossRef]

199. Andress, E.R.; Campbell, J.B. Inundative releases of pteromalid parasitoids (Hymenoptera: Pteromalidae) for the control of stable flies, Stomoxys calcitrans (L.) (Diptera: Muscidae) at confined cattle installations in west central Nebraska. J. Econ. Entomol. 1994, 87, 714-722. [CrossRef]

200. Kaufman, P.E.; Burgess, M.; Rutz, D.A.; Glenister, C.S. Population dynamics of manure inhabiting arthropods under an IPM program in New York poultry facilities -3 case studies. J. Appl. Poult. Res. 2002, 10, 90-103. [CrossRef]

201. Kaufman, P.E.; Long, S.J.; Rutz, D.A.; Waldron, J.K. Parasitism rates of Muscidifurax raptorellus and Nasonia vitripennis (Hymenoptera: Pteromalidae) after individual and paired releases in New York poultry facilities. J. Econ. Entomol. 2001, 94, 593-598. [CrossRef]

202. Meyer, J.A.; Mullens, B.A.; Cyr, T.L.; Stokes, C. Commercial and naturally occurring fly parasitoids (Hymenoptera: Pteromalidae) as biological control agents of stable flies and house flies (Diptera: Muscidae) on California dairies. J. Econ. Entomol. 1990, 83, 799-806. [CrossRef] [PubMed]

203. Weinzierl, R.A.; Jones, C.J. Releases of Spalangia nigroaenea and Muscidifurax zaraptor (Hymenoptera: Pteromalidae) increase rates of parasitism and total mortality of stable fly and house fly (Diptera: Muscidae) pupae in Illinois cattle feedlots. J. Econ. Entomol. 1998, 91, 1114-1121. [CrossRef] [PubMed]

204. Petersen, J.J.; Meyer, J.A.; Stage, D.A.; Morgan, P.B. Evaluation of sequential releases of Spalangia endius (Hymenoptera: Pteromalidae) for control of house flies and stable flies (Diptera: Muscidae) associated with confined livestock in eastern Nebraska. J. Econ. Entomol. 1983, 76, 283-286. [CrossRef] [PubMed]

205. Birkemoe, T.; Soleng, A.; Aak, A. Biological control of Musca domestica and Stomoxys calcitrans by mass releases of the parasitoids Spalangia cameroni on two Norwegian pig farms. Biocontrol 2009, 54, 425-436. [CrossRef]

206. Skovgård, H. Sustained releases of the pupal parasitoid Spalangia cameroni (Hymenoptera: Pteromalidae) for control of house flies, Musca domestica and stable flies Stomoxys calcitrans (Diptera: Muscidae) on dairy farms in Denmark. Biol. Control 2004, 30, 288-297. [CrossRef]

207. Patterson, R.S.; Rutz, D.A. Biological control of muscoid flies. Entomol. Soc. Am. Misc. Publ. 1986, 61, 1-174.

208. Petersen, J.J.; Meyer, J.A. Evaluation of methods presently used for measuring parasitism of stable flies and house flies (Muscidae: Diptera) by Pteromalid wasps (Pteromalidae: Hymenoptera). J. Kans. Entomol. Soc. 1985, 58, 84-90.

209. Legner, E.P.; McKeen, W.D.; Warkentin, R.W. Inoculation of three pteromalid wasp species (Hymenoptera: Pteromalidae) increases parasitism and mortality of Musca domestica L pupae in poultry manure. Bull. Soc. Vector Ecol. 1990, 15, 149-155.

210. Quarles, W. Biological control of nuisance flies with pupal parasitoids. IPM Pract. 2006, 29, 1-9.

211. Dahlman, D.L.; Herald, F.; Knapp, F.W. L-Canavanine effects on growth and development of four species of Muscidae. J. Econ. Entomol. 1979, 72, 678-679. [CrossRef]

212. DeLoach, J.R.; Spates, G.E. Effect of soybean trypsin inhibitor-loaded erthrocytes on fecundity and midgut protease and hemolysis activity of stable flies. J. Econ. Entomol. 1980, 73, 590-594. [CrossRef]

213. Camacho, M.D.R.; Sanchez, B.; Quiroz, H. Pinocembrine: A bioactive flavanone from Teloxys graveolens. J. Ethnopharmacol. 1991, 31, 383-389. [CrossRef]

214. Mehlhorn, H.; Schmahl, G.; Schmidt, J. Extracts of the seeds of the plant Vitex agnus castus proven to be highly efficacious as a repellent against ticks, fleas, mosquitoes and biting flies. Parasitol. Res. 2005, 95, 363-365. [CrossRef] [PubMed]

215. Tobón, F.A.; Fcéutica, Q.M.S. Insecticidal activity of a Melinis minutiflora grass extract on Stomoxys calcitrans flies. Rev. Colomb. Cienc. Pec. 2011, 24, 123-130.

216. Smart, L.E.; Aradottir, G.I.; Bruce, T.J.A. Role of semiochemicals in Integrated Pest Management. In Integrated Pest Management: Current Concepts and Ecological Perspective, 1st ed.; Abrol, D.P., Ed.; Elsevier Inc.: San Diego, CA, USA, 2014; pp. 93-109.

217. Mann, R.S.; Kaufman, P.E.; Butler, J.F. Evaluation of semiochemical toxicity to houseflies and stable flies (Diptera: Muscidae). Pest Manag. Sci. 2010, 66, 816-824. [CrossRef] 
218. Kaufman, P.E.; Mann, R.S.; Butler, J.F. Insecticidal potency of novel compounds on multiple insect species of medical and veterinary importance. Pest Manag. Sci. 2011, 67, 26-35. [CrossRef]

219. Wraight, S.P.; Inglis, G.D.; Goettel, M.S. Fungi. In Field Manual of Techniques in Invertebrate Pathology; Lacy, L.A., Kaya, H.K., Eds.; Chapter IV-4; Springer: Dordrecht, The Netherlands, 2007; pp. 223-248.

220. Moraes, A.P.R.; Angelo, I.d.C.; Fernandes, E.K.K.; Bittencourt, V.R.E.P.; Bittencourt, A.J. Virulence of Metarhizium anisopliae to eggs and immature stages of Stomoxys calcitrans. Ann. N. Y. Acad. Sci. 2008, 1149, 384-387. [CrossRef]

221. Moraes, A.P.R.; de Salles, C.M.C.; Bittencourt, V.R.E.P.; Bittencourt, A.J. Antimicrobial activity of Stomoxys calcitrans against Beauvaria bassiana sensu lato. Rev. Bras. Parasitol. V. 2015, 24, 331-339. [CrossRef]

222. Moraes, A.P.R.; Videira, S.S.; Bittencourt, V.R.E.P.; Bittencourt, A.J. Antifungal activity of Stenotrophomonas maltophilia in Stomoxys calcitrans larvae. Rev. Bras. Parasitol. V. 2014, 23, 194-199. [CrossRef]

223. López-Sánchez, J.; Cruz-Vázquez, C.; Lezama-Gutiérrez, R.; Ramos-Parra, M. Effect of entomopathogenic fungi upon adults of Stomoxys calcitrans and Musca domestica (Diptera: Muscidae). Biocontrol Sci. Techn. 2012, 22, 969-973. [CrossRef]

224. González, L. Manual técnico para el manejo rastrojo en cultivo de piña. Ministerio de Agricultura y Ganadería; Ministerio de Agricultura y Ganadería: San José, Costa Rica, 2012.

225. Paganella-Chang, G.; Blanco-Metzler, H.; Vargas-Gutiérrez, M. Manejo de las poblaciones de Stomoxys calcitrans (L.) (diptera: Muscidae) mediante el uso de descomponedores en el rastrojo de piña (Ananas comosus) (L.) Merr. Entomol. Mex. 2015, 2, 312-318.

226. Weeks, E.N.I.; Machtinger, E.T.; Gezan, S.A.; Kaufman, P.E.; Geden, C.J. Effects of four commercial fungal formulations on mortality and sporulation in house flies (Musca domestica) and stable flies (Stomoxys calcitrans). Med. Vet. Entomol. 2017, 31, 15-22. [CrossRef] [PubMed]

227. Moraes, A.P.R.; Bittencourt, V.R.E.P.; Bittencourt, A.J. Pathogenicity of Beauveria bassiana on immature stages of Stomoxys calcitrans. Ciéncia RuralSt. Maria 2010, 40, 1802-1807. [CrossRef]

228. Watson, D.W.; Geden, C.J.; Long, S.J.; Rutz, D.A. Efficacy of Beauveria bassiana for controlling the house fly and stable fly (Diptera: Muscidae). Biol. Control 1995, 5, 405-411. [CrossRef]

229. Oliveira, D.G.P.; Alves, L.F.A.; Sosa-Gómez, D.R. Advances and perspectives of the use of the entomopathogenic fungi Beauveria bassiana and Metarhizium anisopliae for the control of arthropod pests in poultry production. Rev. Bras. Ciênc. Avíc. 2014, 16, 1-12. [CrossRef]

230. Steenberg, T.; Skovgård, H.; Kalsbeek, V.; Jespersen, J.B. Entomopathogenic fungi in flies associated with pastured cattle in Denmark. J. Inverteb. Pathol. 2001, 77, 186-197. [CrossRef] [PubMed]

231. Steinkraus, D.C.; Kramer, J.P. Susceptibility of sixteen species of Diptera to the fungal pathogen Entomophthora muscae (Zygomycetes: Entomophthoraceae). Mycopath 1987, 100, 55-63. [CrossRef]

232. Alves, P.S.A.; Moraes, A.P.R.; de Salles, C.M.C.; Bittencourt, V.R.E.P.; Bittencourt, A.J. Lecanicillium lecanii no controle de estagios ematuros de Stomoxys calcitrans. Rev. Bras. Med. Vet. 2012, 23 (Suppl. 1), 66-72.

233. Cruz-Vazquez, C.; Márquez, J.C.; Lezama-Gutiérrez, R.; Vitela-Mendoza, I.; Ramos-Parra, M. Efficacy of the entomopathogenic fungi Metarhizium anisopliae in the control of infestation by stable flies Stomoxys calcitrans (L.), under natural infestation conditions. Vet. Parasitol. 2015, 212, 350-355. [CrossRef]

234. Lysyk, T.J.; Kalischuk-Tymensen, L.D.; Selinger, L.B. Mortality of adult Stomoxys calcitrans fed isolates of Bacillus thuringiensis. J. Econ. Entomol. 2012, 105, 1863-1870. [CrossRef]

235. Gingrich, R.E. Bacillus thuringiensis as a feed additive to control dipterous pests of cattle. J. Econ. Entomol. 1965, 58, 363-364. [CrossRef] [PubMed]

236. Patterson, R.S.; LaBrecque, G.C.; Williams, D.F. Use of the sterile male technique to control stable flies on St. Croix Virgin Isl. Agric. Food Fair 1973, 53-55.

237. Patterson, R.S.; LaBrecque, G.C.; Williams, D.F. Use of the sterile male technique as an adjunct to insecticidal and physical methods for stable fly control on the island of St. Croix, U.S.V.I. In Isotope and Radiation Research on Animal Diseases and their Vectors; International Atomic Energy Agency: Vienna, Austria, 1980; pp. 283-295, IAEA -SM-240/16.

238. LaBrecque, G.C.; Patterson, R.S.; Williams, D.F.; Weidhaas, D.E. Control of the stable fly, Stomoxys calcitrans (Diptera: Muscidae), on St. Croix, U.S. Virgin Islands, using integrated pest management measures. I. Feasibility of sterile male releases. J. Med. Entomol. 1981, 18, 194-196. [CrossRef] [PubMed] 
239. Williams, D.F.; Patterson, R.S.; LaBreque, G.C.; Weidhaas, D.E. Control of the stable fly, Stomoxys calcitrans (Diptera: Muscidae), on St. Croix, U.S. Virgin Islands, using integrated pest management measures. II. Mass rearing and sterilization. J. Med. Entomol. 1981, 8, 197-202. [CrossRef]

240. Patterson, R.S.; LaBrecque, G.C.; Williams, D.F.; Weidhaas, D.E. Control of the stable fly, Stomoxys calcitrans (Diptera: Muscidae), on St. Croix, U.S. Virgin Islands, using integrated pest management measures: III. Field techniques and population control. J. Med. Entomol. 1981, 18, 203-210. [CrossRef]

241. Hodge, C.F. A new fly trap. J. Econ. Entomol. 1913, 6, 110-112. [CrossRef]

242. Bishopp, F.C. Fly traps and their operation. In USDA Farmers' Bulletin; US Government Printing Office: Washington, DC, USA, 1913; Volume 734, p. 14.

243. Morgan, N.O.; Pickens, L.G.; Thimijan, R.W. House flies and stable flies captured by two types of traps. J. Econ. Entomol. 1970, 63, 672-673. [CrossRef]

244. Hansens, E.J. The stable fly and its effect on seashore recreational areas in New Jersey. J. Econ. Entomol. 1951, 44, 482-487. [CrossRef]

245. Bailey, D.L.; Whitfield, T.L.; Smittle, B.J. Flight and dispersal of the stable fly. J. Econ. Entomol. 1973, 66, 410-411. [CrossRef]

246. Williams, D.F. Sticky traps for sampling populations of Stomoxys calcitrans. J. Econ. Entomol. 1973, 66, 1279-1280. [CrossRef] [PubMed]

247. Gersabeck, E.F.; Merritt, R.W. Vertical and temporal aspects of alsynite panel sampling for adult Stomoxys calcitrans (L.) (Diptera: Muscidae). Fla. Entomol. 1983, 66, 222-227. [CrossRef]

248. Berry, I.L.; Nelson, A.K.; Broce, A.B. Effect of weather on capture of stable flies (Diptera: Muscidae) by Alsynite fiber glass traps. Environ. Entomol. 1986, 15, 706-709. [CrossRef]

249. Broce, A.B. An improved Alsynite trap for stable flies, Stomoxys calcitrans (Diptera: Muscidae). J. Med. Entomol. 1988, 25, 406-409. [CrossRef] [PubMed]

250. Hogsette, J.A.; Ruff, J.P. Comparative attraction of four different fiberglass traps to various age and sex classes of stable fly (Diptera: Muscidae) adults. J. Econ. Entomol. 1990, 83, 883-886. [CrossRef] [PubMed]

251. Agee, H.R.; Patterson, R.A. Spectral sensitivity of stable, face, and horn flies and behavioral responses of stable flies to visual traps (Diptera: Muscidae). Environ. Entomol. 1983, 12, 1823-1828. [CrossRef]

252. Beresford, D.V.; Sutcliffe, J.F. Studies on the effectiveness of Coroplast sticky traps for sampling stable flies (Diptera: Muscidae), including a comparison to Alsynite. J. Econ. Entomol. 2006, 99, 1025-1035. [CrossRef]

253. Wells, R.W. Some observations on electrified screens and traps. J. Econ. Entomol. 1931, 24, $1242-1247$. [CrossRef]

254. Schreck, C.E.; Posey, K.; Gouck, H.K. Evaluation of the electrocutor grid trap baited with carbon dioxide against the stable fly, Stomoxys calcitrans (L.) (Diptera: Muscidae). J. Med. Entomol. 1975, 12, 338-340. [CrossRef]

255. Pickens, L.G. Battery-powered, electrocuting trap for stable flies (Diptera: Muscidae). J. Med. Entomol. 1991, 28, 822-830. [CrossRef]

256. Pickens, L.G.; Mills, G.D., Jr. Solar-powered electrocuting trap for controlling house flies and stable flies (Diptera: Muscidae). J. Med. Entomol. 1993, 30, 872-877. [CrossRef] [PubMed]

257. Urban, J.E.; Broce, A. Killing of flies in electrocuting insect traps releases bacteria and viruses. Curr. Microbiol. 2000, 41, 267-270. [CrossRef] [PubMed]

258. Loughnan, W.F.M. Bourgault's cattle-fly trap. J. Roy. Med. Corps 1930, 54, 208-211.

259. Segal, B. Why not Bourgault's trap for horse-flies. J. Econ. Entomol. 1933, 26, 301-302.

260. Hall, R.D.; Doisy, K.E. Walk-through trap for control of horn flies (Diptera: Muscidae) on pastured cattle. J. Econ. Entomol. 1989, 82, 530-534. [CrossRef]

261. Bruce, W.G. A cattle trap for the control of horn flies. In USDA Bureau of Entomology and Plant Quarantine; USDA Bureau of Entomology and Plant Quarantine: Washington DC, USA, 1940; p. 9.

262. Denning, S.S.; Washburn, S.P.; Watson, D.W. Development of a novel walk-through fly trap for the control of horn flies and other pests on pastured dairy cows. J. Dairy Sci. 2014, 97, 4624-4631. [CrossRef]

263. Adkins, T.R.; Ezell, W.G.J.; Sheppard, D.C.; Askey, M.M.J. A modified canopy trap for collecting Tabanidae (Diptera). J. Med. Entomol. 1972, 9, 183-185. [CrossRef]

264. Mihok, S.; Kang'Ethe, E.K.; Kamau, G.K. Trials of traps and attractants for Stomoxys spp. (Diptera: Muscidae). J. Med. Entomol. 1995, 32, 283-289. [CrossRef] 
265. Djiteye, A.; Diarra, M.; Ouattara, I.; Traore, D. Comparison of the efficacy of different traps and attractants for Tabanidae and Stomoxys in Mali. J. Protozool. Res. 1998, 8, 263-273.

266. Mihok, S. The development of a multipurpose trap (the Nzi) for tsetse and other biting flies. Bull. Entomol. Res. 2002, 92, 385-403. [CrossRef]

267. Mihok, S.; Carlson, D.A.; Krafsur, E.S.; Foil, L.D. Performance of the Nzi and other traps for biting flies in North America. Bull. Entomol. Res. 2006, 96, 387-397. [PubMed]

268. Mihok, S.; Carlson, D.A.; Ndegwa, N. Tsetse and other biting fly responses to Nzi traps baited with octenol, phenols and acetone. Med. Vet. Entomol. 2007, 21, 70-84. [CrossRef]

269. Mihok, S.; Carlson, D.A. Performance of painted plywood and cloth Nzi traps relative to Manitoba and Greenhead traps for Tabanids and stable flies. J. Econ. Entomol. 2007, 100, 613-618. [CrossRef] [PubMed]

270. Laveissiere, C.; Grebaut, P. The trapping of tsetse flies (Diptera: Glossinidae). Improvement of a model: The Vavoua trap. Trop. Med. Parasitol. 1990, 41, 185-192. [PubMed]

271. Thorsteinson, A.; Bracken, G.; Hanec, W. The Manitoba horse fly trap. Can. Entomol. 1964, 96, 166. [CrossRef]

272. Blanco-Metzler, H.; Arguedas-Marin, A. Efecto del color de trampa y tip de adherente en la captura de Stomoxys calcitrans (L.) (Diptera: Muscidae) en el cultivo de pina (Ananas comosus) (L.) Merr (Effect of trap color and sticky adherent type on Stomoxys calcitrans capture in pineapple). Entomol. Mex. 2015, 2, 319-324.

273. Murchie, A.K.; Hall, C.E.; Gordon, A.W.; Clawson, S. Black border increases Stomoxys calcitrans catch on white sticky traps. Insects 2018, 9, 13. [CrossRef] [PubMed]

274. Zhu, J.J.; Zhang, Q.; Taylor, D.B.; Friesen, K.A. Visual and olfactory enhancement of stable fly trapping. Pest Manag. Sci. 2016, 72, 1765-1771. [CrossRef]

275. DeFoliart, G.R.; Morris, C.D. A dry ice-baited trap for the collection and field storage of hematophagous Diptera. J. Med. Entomol. 1967, 4, 360-362. [CrossRef]

276. Thompson, P.H. Sampling haematophagous Diptera with a conical trap and carbon dioxide with special reference to Culex salinarius. Ann. Entomol. Soc. Am. 1967, 60, 1260-1263. [CrossRef]

277. Cilek, J.E. Evaluation of various substances to increase adult Stomoxys calcitrans (Diptera: Muscidae) collections on Alsynite cylinder traps in North Florida. J. Med. Entomol. 1999, 36, 605-609. [CrossRef]

278. Hoy, J.B. Trapping the stable fly by using CO2 or CO as attractants. J. Econ. Entomol. 1970, 63, $792-795$. [CrossRef]

279. Holloway, M.T.P.; Phelps, R.J. The responses of Stomoxys spp. (Diptera: Muscidae) to trap and artificial host odors in the field. Bull. Entomol. Res. 1991, 81, 51-55. [CrossRef]

280. Kongoro, J.A.; Korir, S. The Potential of Acetone-baited Biconical Trap in Controlling Stomoxys calcitrans in the Maasai Mara Campus, Narok County, Rift Valley, Kenya; Maasi Mara University Repository: Narok, Kenya, 2017; Available online: http://hdl.handle.net/123456789/4833 (accessed on 5 February 2020).

281. Pickens, L.G. The use of traps to suppress stable fly populations. In The Stable Fly: A Pest of Humans and Domestic Animals; Thomas, G.D., Skoda, S.R., Eds.; Symposium Proceedings, Entomological Society of America, Baltimore, MD; Agricultural Research Division, Institute of Agricultural and Natural Resources, University of Nebraska: Lincoln, NE, USA, 1992; pp. 130-140.

282. Ruff, J.P. Trapping effectiveness of several combinations of colors and textures of sticky traps for stable flies, Stomoxys calcitrans. Mosq. News 1979, 39, 290-292.

283. Scholl, P.J.; Lowry, S.R.; Rabe, G.G. Modified William's sticky traps used to measure activity of adult stable flies, Stomoxys calcitrans (L.) in eastern Nebraska. Southwest. Entomol. 1985, 10, 32-38.

284. Cilek, J.E. Attractiveness of beach ball decoys to adult Stomoxys calcitrans (Diptera: Muscidae). J. Med. Entomol. 2002, 39, 127-129. [CrossRef]

285. Cilek, J.E. Attraction of colored plasticized corrugated boards to adult stable flies Stomoxys calcitrans (Diptera: Muscidae). Fla. Entomol. 2003, 86, 420-423. [CrossRef]

286. Hogsette, J.A.; Foil, L.D. Blue and black cloth targets: Effects of size, shape, and color on stable fly (Diptera: Muscidae) attraction. J. Econ. Entomol. 2018, 111, 974-979. [CrossRef]

287. Hogsette, J.A.; Kline, D.L. The Knight Stick trap and Knight Stick sticky wraps: New tools for stable fly (Diptera: Muscidae) management. J. Econ. Entomol. 2017, 110, 1384-1389. [CrossRef]

288. Hogsette, J.A.; Ose, G.A. Improved capture of stable flies (Diptera: Muscidae) by placement of knight stick sticky fly traps protected by electric fence inside animal exhibit yards at the Smithsonian's National Zoological Park. Zoo Biol. 2017, 36, 382-386. [CrossRef] 
289. Broce, A.B.; Schwenke, J.R.; Hampton, K.E. Landing patterns of stable flies (Diptera: Muscidae) on the Alsynite cylinder traps: Effect of wind speed and direction. J. Med. Entomol. 1991, 28, 730-733. [CrossRef]

290. Ose, G.A.; Hogsette, J.A. Spatial distribution, seasonality and trap preference of stable fly, Stomoxys calcitrans L. (Diptera: Muscidae), adults on a 12-hectare zoological park. Zoo Biol. 2014, 33, 228-233. [CrossRef]

291. Gilles, J.; David, J.-F.; Duvallet, G.; De La Rocque, S.; Tillard, E. Efficiency of traps for Stomoxys calcitrans and Stomoxys niger niger on Reunion Island. Med. Vet. Entomol. 2007, 21, 65-69. [CrossRef] [PubMed]

292. Meifert, D.W.; Patterson, R.S.; Whitfield, T.; LaBrecque, G.C.; Weidhaas, D.E. Unique attractant-toxicant system to control stable fly populations. J. Econ. Entomol. 1978, 71, 290-292. [CrossRef] [PubMed]

293. Tseng, J.M.; Hogsette, J.A.; Patterson, R.S. Effect of yarn on attractiveness of the Williams trap to Stomoxys calcitrans (Diptera: Muscidae) adults. Fla. Entomol. 1986, 69, 261-263. [CrossRef]

294. Hogsette, J.A.; Ruff, J.P. Permethrin-impregnated yarn: Longevity of efficacy and potential use on cylindrical fiberglass stable fly (Diptera: Muscidae) traps. J. Econ. Entomol. 1996, 89, 1521-1525. [CrossRef]

295. Foil, L.D.; Younger, C.D. Development of treated targets for controlling stable flies (Diptera: Muscidae). Vet. Parasitol. 2006, 137, 311-315. [CrossRef]

296. Hogsette, J.A.; Nalli, A.; Foil, L.D. Evaluation of different insecticides and fabric types for development of treated targets for stable fly (Diptera: Muscidae) control. J. Econ. Entomol. 2008, 101, 1034-1038. [CrossRef]

297. Cardoso, P.G.; Naka, I.M.; Lopes, C.D.; Cancado, P.H.D.; de Barros, A.T.M. Avaliação da eficácia de inseticidas impregnados em tecidos a adultos da moscados-estábulos (Stomoxys calcitrans). In Jornada Cientifica Embrapa Gado de Corte, 15th ed.; Congress Summary, 10-12 June; Empresa Brasileira de Pesquisa Agropecuária, Ministério da Agricultura, Pecuária e Abstecimento: Brasília, DF, Brazil, 2019; p. 15.

298. Black, W.C.; Krafsur, E.S. Use of sticky traps to investigate seasonal trends in the spatial distribution of house flies and stable flies. (Diptera: Muscidae). J. Med. Entomol. 1985, 22, 550-557. [CrossRef]

299. Rugg, D. Effectiveness of Williams traps in reducing the numbers of stable flies (Diptera: Muscidae). J. Econ. Entomol. 1982, 75, 857-859. [CrossRef]

300. Miller, R.W.; Pickens, L.G.; Potts, W.E. Comparison of traps and an integrated program to manage house flies and stable flies on dairy farms. J. Agric. Entomol. 1993, 10, 189-196.

301. Miller, R.W.; Rutz, D.A.; Pickens, L.G.; Geden, C.J. Evaluation of traps and the parasitoid Muscidifurax raptor Girault and Sanders to manage house flies (Diptera, Muscidae) and stable flies (Diptera, Muscidae) on dairy farms. J. Agric. Entomol. 1993, 10, 9-19.

302. Kaufman, P.E.; Rutz, D.A.; Frisch, S. Large sticky traps for capturing house flies and stable flies in dairy calf greenhouse facilities. J. Dairy Sci. 2005, 88, 176-181. [CrossRef]

303. Tam, T.L.; Hogsette, J.; TenBroeck, S. Can attractive sticky traps be used to protect horses from the bites of Stomoxys calcitrans (L.) (Diptera: Muscidae). J. Econ. Entomol. 2019, 112, 2469-2473. [CrossRef] [PubMed]

304. Scholl, P.J. Field population studies of Stomoxys calcitrans (L.) in eastern Nebraska. Southwest. Entomol. 1986, 11, 155-160.

305. Beresford, D.V.; Sutcliffe, J.F. Field measurements of stable fly (Diptera: Muscidae) demography, fecundity, and survival based on daily trap catches at a beef farm in southern Ontario over a 5-yr period. J. Med. Entomol. 2012, 49, 1262-1269. [CrossRef]

306. Taylor, D.B.; Friesen, K.A.; Zhu, J.J. Spatial-temporal dynamics of the stable fly (Diptera: Muscidae) trap catches in eastern Nebraska. Environ. Entomol. 2013, 42, 524-531. [CrossRef]

307. Taylor, D.B.; Friesen, K.A.; Zhu, J.J. Precipitation and temperature effects on stable fly (Diptera: Muscidae) population dynamics. Environ. Entomol. 2017, 46, 434-439. [CrossRef]

308. Mottet, R.S.; Moon, R.D.; Hathaway, M.R.; Martinson, K.L. Effectiveness of stable fly protectants on adult horses. J. Equine Vet. Sci. 2018, 69, 11-15. [CrossRef]

309. Perttu, R.K.; Heins, B.J.; Phillips, H.N.; Endres, M.I.; Moon, R.D.; Sorge, U.S. Effects of mesh leggings on fly pressure and fly avoidance behaviors of pastured dairy cows. J. Dairy Sci. 2019, 103, 546-551. [CrossRef]

310. Kojima, T.; Oishi, K.; Matsubara, Y.; Uchiyama, Y.; Fukushima, Y.; Aoki, N.; Sato, S.; Masuda, T.; Ueda, J.; Hirooka, H.; et al. Cows painted with zebra-like striping can avoid biting fly attack. PLoS ONE 2019, 14, e0223447. [CrossRef] [PubMed]

311. Cook, D.F.; Deyl, R.A.; Lindsey, J.B.; D’Antuono, M.F.; Telfer, D.V.; McPharlin, I.R. Burial and compaction of sandy soils to prevent emergence of adult stable Fly (Diptera: Muscidae) at the soil surface. J. Econ. Entomol. 2020. [CrossRef] 
312. Vargas-Solano, Á.J. Optimización de la descomposición anaeróbica del rastrojo del cultivo de piña (ananas comusus var. comusus cv. md2) para el manejo de la mosca del establo (Stomoxys calcitrans) (dip.: Muscidae) en Río Cuarto, Costa Rica. In Tesis (Licenciatura en Ingeniería en Agronomía); Instituto Tecnológico de Costa Rica, School of Agronomy: Cartogo, Costa Rica, 2019.

313. Morgan, N.O.; Pickens, L.G.; Miller, R.W. Doorway curtains help exclude flies from dairy barns. J. Econ. Entomol. 1972, 65, 1061-1063. [CrossRef]

314. Hill, S.B. Cultural methods of pest, primarily insect, control. Eap Publ. 58. Mcgill Univ. Que. Can. 1990, 36, 35-49.

315. Greene, G.L. Chemical, cultural, and mechanical control of stable flies and house flies. In Rural Flies in the Urban Environment; Thomas, G.D., Skoda, S.R., Eds.; North Central Regional Res. Publ. No. 335; University of Nebraska: Lincoln, NE, USA, 1993; pp. 83-90.

316. Pickens, L.G.; Schmidtmann, E.T.; Miller, R.W. How to control house and stable flies without using pesticides. Argric. Info. Bull. 1994, 673, 1-14.

317. Cruz-Vazquez, C.; Ramos-Parra, M.; Vitela-Mendoza, I.; Garcia-Vazquez, Z.; Quintero-Martinez, M.T. Relationships between stable fly infestation with some physical facility characteristics and sanitation practices in several dairy farms in the state of Aguascalientes, Mexico. Vet. Parasitol. 2007, 149, 246-250. [CrossRef]

318. Gojmerac, W.L. Weekly cleanup limits fly breeding. In Hoard's Dairyman; Hoard's Dairy Farm: Fort Atkinson, WI, USA, 1981; pp. 692-697.

319. Thomas, G.D. Sanitation as a means of suppressing stable fly populations in beef cattle feedlots. In The Stable Fly: A Pest of Humans and Domestic Animals; Thomas, G.D., Skoda, S.R., Eds.; Symposium Proceedings, Entomological Society of America, Baltimore, MD; Agricultural Research Division, Institute of Agricultural and Natural Resources, University of Nebraska: Lincoln, NE, USA, 1992; pp. 119-132.

320. Thomas, G.D.; Skoda, S.R.; Berkebile, D.R.; Campbell, J.B. Scheduled sanitation to reduce stable fly (Diptera: Muscidae) populations in beef cattle feedlots. J. Econ. Entomol. 1996, 89, 411-414. [CrossRef]

321. Bishopp, F.C. The stable fly: How to prevent its annoyance and its losses to livestock. In USDA Farmers Bulletin; US Government Printing Office: Washington, DC, USA, 1939; Volume 1097, p. 20.

322. Griffiths, O.V. Uncovered silage stacks encourage spread of biting flies. New Zeal. J. Agr. 1962, 104, 65-66.

323. Todd, D.H. The biting fly Stomoxys calcitrans (L.) in dairy herds in New Zealand. New Zeal. J. Agr. Res. 1964, 7, 60-79. [CrossRef]

324. Moore, P.A.J.; Daniel, T.C.; Edwards, D.R.; Miller, D.M. Effect of chemical amendments on ammonia volatilization from poultry litter. J. Environ. Qual. 1995, 24, 293-300. [CrossRef]

325. Ashworth, J.R.; Wall, R. Responses of the sheep blowflies Lucilia sericata and Lucilia cuprina to odour and the development of semiochemicals baits. Med. Vet. Entomol. 1994, 8, 303-309. [CrossRef] [PubMed]

326. Sweeney, C.R.; McDonnell, S.; Habecker, P.L.; Russell, G.E. Effect of sodium bisulfate on ammonia levels, fly population and manure $\mathrm{pH}$ in a horse barn. Am. Assoc. Equine Pract. Proc. 1996, 42, 306-307.

327. Sweeney, C.R.; Scanlon, T.; Russell, G.E.; Smith, G.; Boston, R.C. Effect of daily floor treatment with sodium bisulfate on the fly population of horse stalls. Am. J. Vet. Res. 2000, 61, 910-913. [CrossRef] [PubMed]

328. Cook, D.F.; Jenkins, S.N.; Abbott, L.K.; D’Antuono, M.F.; Telfer, D.V.; Deyl, R.A.; Lindsey, J.B. Amending poultry broiler litter to prevent the development of stable fly, Stomoxys calcitrans (Diptera: Muscidae) and other nuisance flies. J. Econ. Entomol. 2018, 111, 2966-2973. [CrossRef]

329. Chamberlain, W.F.; Matter, J.J. Control of stable flies (Diptera: Muscidae) with a unique nitrogen fertilizer, calcium cyanamide. J. Econ. Entomol. 1986, 79, 1573-1576. [CrossRef] [PubMed]

330. Chamberlain, W.F. On the insecticidal principle and timing of treatment of stable fly larvae with calcium cyanamide. Southwest. Entomol. 1988, 13, 235-241.

331. Schmidtmann, E.T. Suppressing immature house and stable flies in outdoor calf hutches with sand, gravel, and sawdust bedding. J. Dairy Sci. 1991, 74, 3956-3960. [CrossRef]

332. Scully, E.; Friesen, K.; Wienhold, B.; Durso, L.M. Microbial communities associated with stable fly (Diptera: Muscidae) larvae and their developmental substrates. Ann. Entomol. Soc. Am. 2017, 110, 61-72. [CrossRef]

333. Kaufman, P.E.; Rutz, D.A.; Waldron, J.K. Common pest flies found in the urban/rural environment and their biological control agents. In Cornell Cooperative Extension; IPM Fact Sheet 102IPMFS1; New York State Integrated Pest Management Program: Ithaca, NY, USA, 2000. 
334. Greene, G.L.; Guo, Y.J. Integrated stable fly (Stomoxys calcitrans) management in confined cattle feedlots. Rec. Res. Dev. Entomol. 1997, 1, 243-250.

335. Axtell, R.C. Integrated fly control program for caged-poultry houses. J. Econ. Entomol. 1970, 63, 400-405. [CrossRef] [PubMed]

336. Axtell, R.C. Fly control in confined livestock and poultry production. Ciba-Geigy Corp. Tech. Monogr. Greensb. NcUs 1986, 1-59.

337. Urech, R.; Green, P.E.; Hogsette, J.A.; Leemon, D.; Skerman, A.G.; Elson-Harris, M.M.; Brown, G.W.; Bright, R.L.; Everingham, G.; O'Shea, V. Integrated pest management for nuisance flies in cattle feedlots. In Queensland Department of Employment; Economic Development and Innovation: Brisbane, QLD, Australia, 2011; p. 19.

338. Campbell, J.B.; McNeal, C.D. A guide to Integrated Pest Management at feedlots and dairies. In Historical Materials from University of Nebraska-Lincoln Extension; Circular EC 80-1536; University of Nebraska: Lincoln, NE, USA, 1979; pp. 1-21. Available online: https://digitalcommons.unl.edu/extensionhist/4335 (accessed on 5 February 2019).

339. Rutz, D.A.; Geden, C.J.; Pitts, C.W. Pest Management Recommendations for Dairy Cattle. In Cornell and Penn State Cooperative Extension Publication; 10M493; New York State Integrated Pest Management Program: Ithaca, NY, USA, 1995; p. 11. Available online: http://hdl.handle.net/1813/42361 (accessed on 5 February 2019).

340. Gerry, A.C.; Peterson, N.G.; Mullens, B.A. Predicting and Controlling Stable Flies on California Dairies. In University of California, Division of Agriculture and Natural Resources; Publication 8258; University of California: Oakland, CA, USA, 2007; p. 11.

341. Watson, D.W.; Waldron, J.K.; Rutz, D.A. Integrated management of flies in and around dairy and livestock barns. In Cornell Cooperative Extension; 102DMFS450.00; New York State Integrated Pest Management Program: Ithaca, NY, USA, 1994; p. 4.

342. Westenbroek, P. Integrated pest management for fly control in Maine dairy barns. In University of Maine Cooperative Extension; University of Maine: Orono, ME, USA, 2002; p. 6.

343. Hogsette, J.A.; Ruff, J.P.; McGowan, J.P. Stable fly integrated pest management (IPM) in northwest Florida. J. Fla Anti-Mosq. Assoc. 1981, 52, 48-52.

(C) 2020 by the author. Licensee MDPI, Basel, Switzerland. This article is an open access article distributed under the terms and conditions of the Creative Commons Attribution (CC BY) license (http://creativecommons.org/licenses/by/4.0/). 